\title{
Boa-fé nos serviços bancários, financeiros , de crédito e securitários e o Código de Defesa do Consumidor: informação,
} cooperação e renegociação? ${ }^{1}$

\section{Claudia Lima Marques}

Professora titular da Universidade Federal do Rio Grande do Sul, Porto Alegre. Doutora em Direito pela Universidade de Heidelberg, Alemanha. Mestre em Direito pela Universidade de Tübingen, Alemanha. Especialista em Direito Europeu pela Universidade do Sarre, Alemanha. Coordenadora do PPGDir./ UFRGS. Ex-Presidente do Instituto Brasileiro de Política e Direito do Consumidor-BRASILCON.

\section{Introdução}

O título deste $6^{\circ}$ Congresso Brasileiro de Direito do Consumidor, organizado pelo Brasilcon, é sugestivo: "Serviços Bancários, Financeiros, de Crédito e SecuritáriosFunção Social, Boa-fé e Responsabilidade". Realmente, o que teriam estes diversos contratos, estas diversas atividades, estes diversos serviços (bancários, financeiros , de crédito e securitários), em comum, a não ser o fato da menção específica no Art. $3 \stackrel{\circ}{\circ} \S$ $2 \%$ do CDC in fine?

Bancare/garantir, fides/fé/Treu/financiar/confiar, credere/acreditar/crer/glauben, segurar/seguro/assegurar. Sim, efetivamente estes 4 contratos, estas 4 operações, estas 4 atividades econômicas, estes 4 serviços colocados a disposição dos consumidores no

\footnotetext{
1 Versão atualizada da Conferência apresentada no 6ํㅡㄹ Congresso Brasileiro de Direito do Consumidor e $2^{0}$ Encontro Nacional do Ministério Público do Consumidor: Serviços Bancários, Financeiros, de Crédito e Securitários- Função Social, Boa-fé e Responsabilidade, organizado pelo Brasilcon e Associação Nacional do Ministério Público do Consumidor, em Maceió, de 29 a 31 de maio de 2002. Texto original e formado por extratos da $4^{\text {a }}$ edição do livro Contratos no Código de Defesa do Consumidor, RT, São Paulo, 2002.
} 
mercado brasileiro têm um elemento em comum que os domina: fides, de fidelidade, de acreditar, de assegurar, de crer, de confiar, no outro ! Boa-fé é um pensar refletido, é o pensar no outro, no mais fraco, no parceiro contratual, nas suas expectativas legítimas, é lealdade, é transparência, é informação, é cooperação, é cuidado, é visualização e respeito pelo outro. Estes 4 serviços do título de nosso congresso são, pois, fazeres complexos, grupos de contratos, sistemas de operações, serviços conexos, contratos de adesão, guiados todos por um paradigma básico que deve ser a boa-fé (Treu und Glauben).

O Código de Defesa do Consumidor brasileiro (Lei 8.078/90) realmente impóe a transparência (art. 4 caput), o princípio da Boa-fé objetiva (art. 4 , III) e a ativa proteção do consumidor com base na Boa-fé de condutas (Art. 51, IV e $\S 1^{\circ}$ ) e na interpretação dos contratos conforme a confiança despertada (art. 30, 34, 35, 47 e 48 todos do CDC). Da mesma forma, o novo Código Civil aprovado em 2002 cria deveres com base na boa-fé (Art. 422), impóe limites (art. 187) e uma interpretação guiada por esta Boa-fé objetiva (Art. 113). Neste trabalho, considero que o CDC aplica-se totalmente aos serviços bancários, financeiros, de crédito e securitários, apesar da ADIN do CONSIF ainda estar sob análise. De qualquer forma, indiscutível que a boa-fé, a do CDC e a do CC/2002 aplica-se a estes contratos

Geralmente a análise dos contratos bancários, financeiros, de crédito e securitários concentra-se nas cláusulas abusivas presentes nestes contratos ou na aplicação ou não do CDC a alguns destes contratos. Neste congresso, inspirada pelo título e tendo em vista que estes temas serão objeto de outras palestras dos colegas do Brasilcon, quero concentrar-me nas positivas funções da boa-fé nestes contratos (Parte I), especialmente, no que se refere aos deveres de conduta positiva existentes nestes contratos, se iluminados pelo princípio da boa-fé do CDC, o dever de informar e o dever de cooperar (Parte II). Não se trata de um tema teórico, mas eminente prático e valorativo para o julgador, dai sua importância.

Assim, nosso objeto de investigação da primeira Parte serão as funções da boafé no CDC e como estas funções influenciam a nossa nova visão do contrato entre bancos, empresas financiadoras, administradoras de cartóes de crédito, seguradoras e outros fornecedores com consumidores. E, na segunda parte, analisaremos os deveres de conduta, o dever de informar e de transparência específica do meio financeiro presentes nestes contratos e como estes devem influenciar a forma da magistratura interpretar estes contratos, e valorar as cláusulas e as práticas comerciais destes fornecedores; assim como o dever de cooperar e o nascente dever de renegociar estes contratos de forma a evitar o superendividamento. A escolha destes dois deveres de boa-fé (informação e cooperação) deve-se ao recente lançamento, no mercado editorial 
Boa-fé nos serviços bancários, financeiros, de crédito e securitários e o Código de Defesa do Consumidor

brasileiro, de dois livros específicos sobre o tema, ${ }^{2}$ que tive as honra de prefaciar, ${ }^{3}$ assim como a sua importância na doutrina germânica atual.

I- As funções da boa-fé no CDC e sua potencialização nos contratos bancários, financeiros, de crédito e securitários

Inicialmente, nosso objeto de investigação inicial serão as funções da boa-fé no $\mathrm{CDC}(\mathrm{A})$ e como estas funçōes influenciam a nossa nova visão do contrato com consumidores (B), em especial sua potencialização nos contratos bancários, financeiros, de crédito e securitários.

Observando a doutrina brasileira atual, nota-se que as análises sobre as funções da boa-fé são geralmente baseadas na obra clássica de Franz Wieacker e nos estudos da década de 50-60 de Larenz e Canaris, da Universidade de Munique, em especial, sobre a importância das cláusulas gerais no sistema do direito privado. ${ }^{4}$ No momento (2000/ 2001) em que o Código Civil Alemão-BGB é profundamente reformado, a ponto de mencionar a doutrina germânica atual, o nascimento de um "novo BGB", gostaria de contribuir a esta discussão trazendo as teorias de autores atuais germânicos de minha alma mater , a Universidade de Heidelberg, ainda não traduzidos para o português, em especial do Professor Othmar Jauernig e seus comentários ao BGB. Mister também reler as teorias de Karl Engish e Franz Wieacker, sob a luz da insegurança pós-moderna, lançada por outro Professor de Heidelberg, Prof. Dr. Dr. h. c. mult. Erik Jayme, ${ }^{6}$ assim

\footnotetext{
2 Veja de FABIAN, Christoph, O dever de informar no Direito Civil, RT, São Paulo, 2002 e de MARTINS DA COSTA, Geraldo de Faria, Superendividamento: A proteção do consumidor de crédito em direito comparado brasileiro e francês, RT, São Paulo, 2002, no prelo.

${ }^{3}$ Do prefácio de FABIAN, destaco, p. 9: "De forma didática, simples e direta, como é característica dos mestres alemães, este jovem jurista - agora brasileiro- constrói com base na jurisprudência dos Interesses (de Jhering) a reflexão dogmática que estava faltando na doutrina brasileira: qual a origem do dever de informar ? Em que relações está presente este dever de boa-fé? Que agentes da sociedade detêm realmente o direito subjetivo (público ou privado) de serem informados? A que agentes da sociedade foi imposto o dever de informar ? Quais os limites deste dever de conduta segunda a boa-fé?" e do prefácio de MARTINS DA COSTA, concluo, p. 1: "Efetivamente estava faltando na doutrina brasileira um estudo sério, inspirador, ao mesmo tempo didático, simples e informativo sobre o tema, considerado quase "tabu" pelas Instituições financeiras e Administradoras de Cartões de Crédito, face à grande insolvência dos consumidores no Brasil. Seguindo os passos da tese premiada de Nicole Chardin (de 1988)..., Geraldo de Faria Martins da Costa sugere uma releitura da lei brasileira para incluir um prazo de reflexão em matéria de contratos de crédito ao consumidor e uma melhor regulação das garantias conexas ao crédito, a evitar o superendividamento, assim como modificação da legislação brasileira para criar possibilidades de tratar e superar o superendividamento, quando este ocorre em virtude do consumo." ${ }^{4}$ Veja-se as obras atuais de Judith Martins Costa, Nelson Nery Júnior e Tércio Ferraz Jr., para citar as mais importantes, magnificamente sintetizadas na obra de NERY, Nelson Júnior e NERY, Rosa Maria de Andrade, Novo Código Civil e legislação extravagante-anotados, RT, São Paulo, 2002, p. 4 a 7.

${ }^{5}$ A expressão sensacionalista é usada por Alpmann-Pieper, Annergerd e Becker, Peter, in ExpressPeform des Schuldrechts-Das neue BGB, 2.ed, Alpmann Schmidt V., Münster, 2002, obra menor para estudantes alemães, veja resumo das modificações, in WIESER, Eberhard, "Eine Revolution des Schuldrechts", in NJW 2001, p. 121 a 124.

${ }^{6}$ Veja o famoso curso de JAYME, Erik, Identité culturelle et intégration: Le droit internationale privé postmoderne - in: Recueil des Cours de l' Académie de Droit International de la Haye, 1995,II, p. 36 e seg.
} 
como os novos estudos de Canaris, de 2001 sobre materialização dos contratos, ${ }^{7}$ e no seu manual conjunto de 1994 sobre obrigaçōes de Larenz e Canaris. ${ }^{8}$

A) As funções clássicas da boa-fé no CDC e no novo Código Civil de 2002

Como escrevemos, ${ }^{9}$ boa-fé é um princípio de repersonalização da relação contratual. Como ensina o grande mestre da UFRGS, Clóvis do Couto e Silva: "...o dever que promana da concreção do princípio da boa fé é dever de consideração para com o 'alter'." ${ }^{10}$ Efetivamente, boa-fé objetiva significa uma atuação "refletida", 11 uma atuação refletindo, pensando no outro, no parceiro contratual, respeitando-o, respeitando seus interesses legítimos, suas expectativas razoáveis, seus direitos, agindo com lealdade, sem abuso, sem obstrução, informando-o, aconselhando-o, cuidando, sem causar lesão ou desvantagem excessiva, cooperando para atingir o bom fim das obrigações: o cumprimento do objetivo contratual e a realização dos interesses das partes. ${ }^{12}$

Boa-fé é cooperação e respeito, é conduta esperada e leal, tutelada em todas as relações sociais. A proteção da boa-fé e da confiança despertada formam, segundo Couto e Silva, a base do tráfico jurídico, a base de todas as vinculações jurídicas, o princípio máximo das relações contratuais. ${ }^{13}$ A boa-fé objetiva e a função social do contrato são, na expressão de Waldírio Bulgarelli, "como salvaguardas das injunçóes do jogo do poder negocial". ${ }^{14}$

Na visão mais difundida entre nós, o Princípio da boa-fé na formação e na execução das obrigações possui três funções principais ${ }^{15}$ :

1) como fonte de novos deveres especiais de conduta durante o vínculo contratual (pflichtenbegrundende Funktion), função criadora dos chamados deveres anexos (Nebenpflichten), deveres de conduta anexos aos deveres de prestação contratual, como o dever de informar, o dever de cuidado e de cooperação, e

2) como causa limitadora do exercício, antes lícito, hoje abusivo, dos direitos subjetivos, uma função limitadora ( Schranken-bzw. Kontrollfunktion), reduzindo a

\footnotetext{
7 Veja CANARIS, Claus-Wilhelm, "Wandlungen des Schuldvertragsrechts- Tendenz zu seiner 'Materialisierung' ", in Archiv für die civilistische Praxis (AcP), 200 (2000), p. 277 e seg.

"Vela LARENZ, Karl e CANARIS, Claus-Wilhelm, Lehrbuch des Schuldrechts-Besonderer Teil-2.Hb., 13.ed., Beck, Munique, 1994. (citado LARENZ/CANARIS)

${ }^{9}$ Veja nosso livro Contratos, $4^{\mathrm{a}}$ edição, no prelo.

${ }^{10}$ COUTO E SILVA, Clóvis V. A Obrigação como Processo, São Paulo, Ed. J. Bushtasky, 1976 p. 29.

11 Veja nosso livro, MARQUES, Cláudia Lima, Contratos no Código de Defesa do Consumidor, 4. edição especial de 10 anos do CDC, RT, São Paulo, 2002, no prelo.

12 Sobre boa-fé como regra de conduta, como limite à autonomia da vontade e como fonte de novos deveres acessórios, veja a obra de MENEZES CORDEIRO, Antonio M. da Rocha e, "Da Boa-fé no Direito Civil", vol. 1, pp. 632 e ss.

${ }^{13}$ Veja COUTO E SILVA, op. cit.op. cit, p. 44 e seg.

${ }^{14}$ BULGARELLI, Valdírio, Questões contratuais no CDC, $2^{\text {a }}$ ed., Atlas, São Paulo, 1998 p. 99.

${ }^{15}$ LARENZ, Karl, Lehrbuch des Schuldrechts, Bd. 1, Allgemeiner Teil, 14, Aufl., München, Beck, 1987, pp. 26, 27, 28.
} 
Boa-fé nos serviços bancários, financeiros, de crédito e securitários e o Código de Defesa do Consumidor

liberdade de atuação dos parceiros contratuais ao definir algumas condutas e cláusulas como abusivas, seja controlando a transferência dos riscos profissionais e libertando o devedor face a não razoabilidade de outra conduta ( $p$ flichenbefreinde Vertrauensunstände) $16 \mathrm{e}$

3) na concreção das relações e na interpretação dos contratos, função interpretadora, pois a melhor linha de interpretação de um contrato ou de uma relação de consumo deve ser a do princípio da boa-fé, o qual permite uma visão total e real do contrato sob exame. ${ }^{17}$

O Código de Defesa do Consumidor, Lei 8.078/90, trouxe como grande contribuição a exegese das relações contratuais no Brasil a positivação do princípio da boa-fé objetiva, como linha teleológica de interpretação, em seu art. 4, III e como cláusula geral, em seu art. $51, \mathrm{~N}$, positivando em todo o seu corpo de normas a existência de uma série de deveres anexos às relaçōes contratuais.

Também o novo Código Civil, Lei 10.406 , de 10 de janeiro de 2002, traz o princípio da boa-fé como orientador dos contratos civis e comerciais, seja 1) na criação de deveres: "Art. 422. Os contratantes são obrigados a guardar, assim na conclusão do contrato, como em sua execução, os princípios de probidade e boa-fe"'; seja 2) na definição de limites: "Art. 187. Também comete ato ilícito o titular de um direito que, ao exercê-lo, excede manifestamente os limites impostos pelo seu fim econômico ou social, pela boa-féou pelos bons costumes"; ou seja 3) na interpretação: “Art. 113. Os negócios jurídicos devem ser interpretados conforme a boa-fé e os usos do lugar de sua celebraçáo."

Observe-se que estas cláusulas gerais, bastante elogiadas pela doutrina, ${ }^{18}$ tem um formato clássico, mas grande potencialidade. O Código Civil de 2002 é um código para iguais, um código para civis em suas relaçōes e para comerciantes ou empresários em suas relações comerciais entre si. Náo trata das relações de consumo, que são relações em princípio entre um leigo, civil ,o consumidor (art. $2^{\circ}$ do CDC), e um profissional, um empresário, o fornecedor (art. $3^{\circ}$ do $\mathrm{CDC}$ ). Para estas relações entre desiguais (art. 4,I do CDC), relações mistas, o direito brasileiro, desde 1988 (Art. 48 ADTC) reservou uma proteção especial do consumidor (art. 10 do CDC) e aplica-se prioritariamente o Código de Defesa do Consumidor, como lei especial.

Interessante notar que as cláusulas gerais sobre boa-fé (e função social) mais importantes do Novo Código Civil, para os temas contratuais (Art. 421,422) já se encontram sob o perigo de serem modificadas, assim como as que dizem respeito aos contratos de adesão, dificultando uma manifestação momentânea sobre o assunto. De qualquer forma, mencione-se que o antes mencionado texto do Art. 422 do CCB/ 2002, através de projeto de lei 6960 do Deputado Ricardo Fiúza, de 12 de junho de 2002, poderia passar a receber esta redação: “ Art. 422. Os contratantes são obrigados a

\footnotetext{
${ }^{16}$ Veja, por todos, FIKENTSCHER, Wolfgang, Schuldrecht, Walter de Gruyter, Berlim, 1992 Wolfgang, Schuldrecht, Walter de Gruyter, Berlim, 1992, p.130 e seg.

17 BULGARELLI, op. cit., p. 95 .

${ }^{18}$ Veja, por todos, NERY/NERY, p. 6.
} 
guardar, assim nas negociaçōes preliminares e conclusão do contrato, como em sua execução e fase pós-contratual, os princípios de probidade e boa-fé e tudo mais que resulte da natureza do contrato, da lei, dos usos e das exigências da razão e da equidade".

Esta projetada redação menciona expressamente a eficácia pré-contratual e pós-contratual da boa-fé, mas pode ser criticada por denominar a boa-fé de "princípio" e de maneira ampla incluir na concretizaçáo da boa-fé "tudo mais que resulte da natureza do contrato, da lei, dos usos e das exigências da razáo e da equidade". Mençóes em demasia, em uma cláusula geral clássica, podem ser negativas. Melhor seria retirar a expressão "princípios", por desnecessária, e o final da frase. Em especial a menção "da lei" é supérflua, pois, por natural a lei deve ser cumprida pelas partes. Também a expressão "exigências da razão", em tempos pós-modernos, é de reduzidíssima eficácia, sendo quase discursiva. Fortes são as menções à equidade, em pleno código civil unitário, civil e comercial, e na parte geral deste Código novo, a denotar quase a ilimitada eficácia desta norma e à natureza do contrato (o que também é mencionado no $\$ 10$ do Art. 51 do $(D C$ ). Face a potencialidade negativa desta nova redação, tendo a considerar que seria melhor manter a anterior, mais sintética e elegante. Suas falhas e imprecisões podem ser completadas pelo Direito dos juizes, como é normal em matéria de cláusulas gerais. O $§ 242$ do BGB é bastante sintético e só menciona a "prestação", logo, a execução e mesmo assim teve significativa evolução jurisprudencial.

Note-se que o projeto de lei inclui uma menção expressa da boa-fé bilateral, do aderente e do segurado, no contrato de seguro, afirmando: “Art. 765. O segurado e o segurador são obrigados a guardar, assim nas negociações preliminares e conclusão do contrato, como em sua execução e fase pós-contratual, os princípios da probidade e boa-fé, tanto a respeito do objeto como das circunstâncias e declaraçóes a ele concernentes". Note-se que aqui se incluiu novamente a menção ao "princípio" da boa-fé como se esta pudesse tornar a análise da boa-fé subjetiva no caso concreto, em análise objetiva. Quem fará este exercício é o julgador. A versão atual do Art. 765 repete a norma atual do $\mathrm{CCB} / 16$ : “Art. 1.443. O segurado e o segurador são obrigados a guardar no contrato a mais estrita boa-fé e veracidade, assim a respeito do objeto, como das circunstâncias e declaraçōes a ele concernentes." Note-se que em matéria de seguros, o Art. 777 do novo Código Civil ${ }^{19}$ bem explicita que a aplicação destas normas é subsidiária à da lei especial, no caso a do CDC para os seguros envolvendo consumidores, dai já ter a jurisprudência brasileira chegado a esta objetivação. ${ }^{20}$

Destaque-se também que o projeto do Deputado Fiúza pode criar mais uma cláusula geral de bons costumes e conexidade negocial no Art. 425 sobre contratos

\footnotetext{
${ }^{19}$ O texto é: "Art. 777: "O disposto no presente capítulo aplica-se, no que couber, aos seguros regidos por leis especiais".

${ }_{20}$ Veja REsp. 258.805-MG, j. 27.09.2000, Min. Ruy Rosado de Aguiar, cuja ementa é: "Acidente no trabalho. Seguro de vida em grupo. Tenossinovite. Doença preexistente. A seguradora que aceita 0 contrato e recebe durante anos as contribuições da beneficiária do seguro em grupo não pode recusar o pagamento da indenização, quando comprovada a invalidez, sob a alegação de que a tenossinovite já se manifestara anteriormente."
} 
Boa-fé nos serviços bancários, financeiros, de crédito e securitários e o Código de Defesa do Consumidor

atípicos, que atingiria de frente os contratos atípicos de cartões de crédito e de financiamento conexo ao consumo. A norma projetada é a seguinte: "Art. 425. É lícito às partes estipular contratos atípicos, resguardados a ordem pública, os bons costumes e os princípios gerais de direito, especialmente o princípio de que suas obrigações são indivisíveis, formando um só todo". Qual exatamente é ratio de tal norma, ainda não conseguimos verificar. Se aprovada, seus efeitos podem ser enormes, ao permitir um mais forte controle do Judiciário nestes contratos atípicos.

Por fim, mencione-se que o Projeto do Deputado Fiúza, na versão de 12 de junho de 2002, copia -substituindo a palavra fornecedor por contratante, consumidor por aderente-o Art. 54 do CDC no projetado Art. 423 e inclui em seu parágrafo $2^{\circ} \mathrm{a}$ regra do Art. 47 do CDC. O texto projetado seria o seguinte: "Art. 423. Contrato de adesão é aquele cujas cláusulas tenham sido aprovadas pela autoridade competente ou estabelecidas unilateralmente por um dos contratantes, sem que o aderente possa discutir ou modificar substancialmente seu conteúdo. Parágrafo $1^{\circ}$ - Os contratos de adesão escritos serão redigidos em termos claros e com caracteres ostensivos e legíveis, de modo a facilitar sua compreensão pelo aderente. Parágrafo $2^{\circ}$. As cláusulas contratuais, nos contratos de adesão, serão interpretadas de maneira mais favorável ao aderente." Considerando que muitos contratos considerados civis -eu particularmente considero de consumo ${ }^{21}$, , como o de locação, hoje são contratos de adesão e que muitos contratos comerciais, inter-empresários, são de adesão, parece-me salutar esta substituição da regra clássica da interpretação agora presente no texto do Art. 423. Mencione-se ainda que o projeto traz mais duas contribuições do CDC à dogmática geral do direito civil: a força vinculatória da publicidade (no projetado Art. 429) ${ }^{22}$ e a idéia de danos morais satisfatórios ou desestimulantes, para náo dizer punitivos (no projetado Art. 944, § 2\%). ${ }^{23}$

Boa-fé é, em resumo, um princípio de materialização da vontade contratual, agora balizada pelas exigências de considerara as expectativas legítimas do outro. ${ }^{24}$ Assim ensina o também grande mestre da UFRGS, Ruy Rosado de Aguiar ${ }^{25}$ : "A boa-fé se constitui numa fonte autônoma de deveres, independente da vontade, e por isso a extensão e o conteúdo da relação obrigacional já não se mede somente nela (vontade), e, sim, pelas circunstâncias ou fatos referentes ao contrato, permitindo-se construir objetivamente o regramento do negócio jurídico, com a admissão de um dinamismo que escapa ao controle das partes." (grifo nosso) Para se ter a importância desta visão renovadora dos contratos envolvendo consumidores e fornecedores, ensina Paulo Luiz Neto Lôbo: "O princípio da boa-fé objetiva foi refuncionalizado no direito do

\footnotetext{
${ }^{21}$ Veja defesa desta teoria minoritária, em meu livro Contratos, $4^{\mathrm{a}}$ edição, no prelo.

22 O texto projetado é: "Art. 429. A oferta ao público eqüivale à proposta, obrigando o proponente, quando suficientemente precisa a informação ou a publicidade, salvo se o contrário resultar das circunstâncias ou dos usos".

${ }^{23} \mathrm{O}$ texto projetado é: "Art. 944. ...parágrafo $2^{\circ}$ A reparação do dano moral deve constituir-se em compensação ao lesado e adequado desestímulo ao lesante".

${ }^{24}$ Assim CANARIS, in Archiv für die civilistische Praxis (ACP), 200 (2000), p. 277 e seg.

${ }^{25}$ AGUIAR, Ruy Rosado de, "A Boa-fé na relação de consumo", in Direto do Consumidor, vol. 14, p. 24.
} 
consumidor, otimizando-se sua dimensão de cláusula geral, de modo a servir de parâmetro de validade dos contratos de consumo, principalmente nas condiçóes gerais dos contratos." 26

B) As funções potencializadas da boa-fé segundo a doutrina germânica atual e a análise do CDC

Se esta visão da boa-fé é importante e fundamental, parece-me chegada a hora de evoluirmos e, neste conclave, estudarmos as funções potencializadas da Boa-fé, como os doutrinadores germânicos estão as concebendo no início do século XXI. A primeira premissa, trazida pelo Professor de Heidelberg, Jauernig, é a dupla medida que a Boa-fé representa. Isto é, não podemos pensar o princípio da boa-fé como simples instrumento para medir (ou guiar) a conduta das partes, dos Bancos, das Administradoras de Cartōes de Crédito, das Seguradoras, das financiadoras, das operadoras de Leasing etc. A boa-fé objetiva é também, e principalmente, um instrumento de decisão, de valoração dos juizes, das condutas e cláusulas, dos atos pretéritos e futuros destes Bancos, das Administradoras de Cartões de Crédito, das Seguradoras, das financiadoras, das operadoras de Leasing etc. ${ }^{27}$

1) As funções potencializadas da boa-fé segundo Jauernig

Como ensinam Jauernig e Vollkommer, a boa-fé objetiva trata-se, ao mesmo tempo, de uma medida objetiva (objektive Masstab), um paradigma de conduta para as partes, e uma medida de decisão (Entscheidungsmasstab), um instrumento objetivo de apreensão da realidade pelo juiz. ${ }^{28}$

Segundo Jauernig e Vollkommer, as quatro funçōes atuais da boa-fé seriam:

a) função de complementação ou concretização da relação (Ergänzungsfunktion), podendo o aplicador da lei, através do princípio da boa-fé objetiva, visualizar e precisar quais os deveres e direitos decorrentes daquela relação em especial (por exemplo, incluindo as informações veiculadas em publicidade por uma seguradora

${ }^{26}$ LOBO, Paulo Luiz Neto "A informação como direito fundamental do consumidor", in Direito do Consumidor 37, p. 67.

${ }_{27}$ Veja decisão do TJRS, APC 70000037408, j. 18.10.2000, Des. Paulo Augusto Monte Lopes, $16^{\mathrm{a}}$ Câm. Cível.: "Em qualquer negócio, seja qual for a natureza, seja qual for o regime jurídico aplicável, o direito protege a boa-fé. Proteger a boa-fé significa preservar os contratantes de artimanhas e subterfúgios. Como o contrato é lei entre as partes, e uma delas pode - por sua vulnerabilidade ou hipossuficiência diante da outra - ter assinado o instrumento sem compreender por completo tudo o que nele se dispôs ou mesmo por vício, o direito ampara os interesses desse contratante fazendo prevalecer sobre a literalidade do contrato os reais objetivos pretendidos na contratação." (p. 4 do original)

${ }_{28}$ Assim ensinam JAUERNIG, Othomar et alli, Bürgerliches Gesetzbuch, 7.ed, Beck, Munique, 1994, p.172, § 242,1 (Vollkommer). 
Boa-fé nos serviços bancários, financeiros , de crédito e securitários e o Código de

Defesa do Consumidor

ou grupo bancário, Art. 30 do CDC), ${ }^{29}$ também chamada de função interpretativa. ${ }^{30}$ A expressão alemã é de valorar-se e destacar-se, pois bem especifica a função ativa do juiz, uma vez que se trata do Richterrecht (Direito dos Juizes), isto é, há uma atividade mais completa e complexa ${ }^{31}$ do que a simples interpretação pelo juiz, há, sim, concreção de cláusula geral..$^{32} \mathrm{E}$ como ensina a Corte Constitucional alemã desde $1993,{ }^{33}$ na concreção das cláusulas gerais de boa-fé e bons costumes (em especial, nos contratos bancários, financeiros e de crédito) as cortes civis devem fazer valer os direitos humanos, os direitos fundamentais recepcionados nas Constituições, ${ }^{34} \mathrm{impregnando}$ o direito privado de seu espírito de proteção da dignidade da pessoa humana, da privacidade, de proteção dos dados, de direito à informação, à escolha livre, de desenvolvimento da sua personalidade etc.

A expressão atual alemã também esclarece que a boa-fé é fonte de deveres (deveres anexos), "descobertos" na complementação, na "fotografia" da relação, que realiza o magistrado: informar, cooperar, cuidar com o outro e, não só, prestar... Aqui, está, pois, a função primeira e mais complexa da boa-fé, que valora o grau de informação, de transparência, de lealdade nas condutas e cláusulas dos Bancos, das Seguradoras,

${ }^{29}$ Belo exemplo é a decisão do TJ/RS, já citada: "Propaganda enganosa. Garantia, incondicional, de financiamento para aquisiçāo de unidade imobiliária. Aplicabilidade do Código de Defesa do Consumidor. Propaganda enganosa que garantiu, incondicionalmente, financiamento à aquisição de unidade imobiliária. Improvadas as apontadas irregularidades na documentação. Com inversāo do ônus sucumbencial, condenação da incorporadora para suportar, às suas próprias expensas, o parcelamento da dívida (conforme garantido na publicidade)."(AC 598435063,Des. Guinther Spode

j.22.12.98, in RDC 36/324). Veja também decisão e as já citadas decisões do TJ/RS sobre embalagem prometendo prêmios (AC 596126037, 5a Câm. Civ. TJ RS, j. em 22.08.96, rel. Des. Araken de Assis) e sobre publicidade prometendo carros a quem completasse um 'bingo' (AC 596116764, $5^{\mathrm{a}}$ Câm. Cív. TJ RS, j. em 14.11.96, rel. Des. Araken de Assis), todas citadas e comentadas no belo artigo de Guinther Spode, "O controle da publicidade à luz do CDC", in RDC 42 (2002), no prelo. Veja também sobre promessa de recompensa e premiação de tampa de vasilhame de refrigerante Resp. 289.346/MG, DJ 25.06.2001, min. Nancy Andrighi. 30 É o que MARTINS-COSTA, Judith, Boa-fé no Direito Privado, RT, São Paulo, 2001, p.428, denomina de 'a boa-fé como cânone hermenêutico-integrativo' e à p. 431, citando Larenz, denomina 'interpretação da regulação objetiva criada com o contrato".

${ }^{31}$ Belo exemplo pode ser a decisão do TJ/RS, em caso envolvendo seguro de "condom

ínio Residencial", em que cláusula contratual dava direito ao conserto do elevador somente após "comunicação" à seguradora e in APC598002079, j. 03.06.1998, Des. Antônio Janyr Dall'Agnol J

únior ensinou: "Seguro de dano. Interpretação de cláusula. comunicação imediata, não necessariamente prévia. dano em elevador de edifício de apartamentos residenciais. Segundo interpretação que se ostenta a melhor, a exigência, em casos como o dos autos, é de comunicação, sim, e imediata, mas não necessariamente prévia, do dano em elevador de edifício de apartamentos residenciais, pois desarrazoado que se aguarde providências da seguradora, para, apenas após, efetivar o conserto, sempre urgente quando se cuida deste meio de transporte de pessoas. "

${ }^{32}$ Assim também no Brasil, TEPEDINO, Gustavo (Coord.), Direito Civil-Constitucional, Renovar, rio de Janeiro, 201, p. 11 e 12: "as cláusulas gerais que, previstas pelo legislador contemporâneo, no Código de Defesa do Consumidor..., vêm sendo amplamente utilizadas pelos operadores. Recupera-se, então, o papel da jurisprudência e da doutrina..."

${ }_{33}$ BVerfG Beschl. v. 19.101993 - 1BvR 567/89 u.la., in: NJW 1994,36. A ementa original é a seguinte: „Die Zivilgerichte müssen - insbesondere bei der Konkretisierung und Anwendung von Generalklauseln wie § 138 und \$242 BGB - die grundrechtlcihe Gewährleistung der Privatautonomie in Art. 2,I GG beachten. Daraus ergibt sich ihre Pflicht zur Inhaltskontrole von Verträge, die einen der beiden Vertragspartner ungewöhnlich stark belasten und das Egbnis strukturell ungleicher Verhandlungsstärke sind."

34 Veja meu artigo "Os contratos de crédito e a legislação brasileira de proteção do consumidor", in RDC vol 18, p. 53-76. 
das Administradoras, das Financeiras e Operadoras, de forma a visualizar/fotografar que relaçáo jurídica é esta, complexa, conexa, principal ou acessória visando o consumo e se as exigências desta boa-fé foram ou podem ser cumpridas. O objetivo é alcançar a igualdade, o reequilibro entre as partes, e a atuação do Juiz conforme a boa-fé é ativa, como ensina o TJ/RS:

"Ao analisar o contrato, com suas diversidade, e que se constitui alvo especial do chamado Direito do Consumidor, está o juiz nesse alinhamento bem longe da principiologia clássica do contrato, onde se presumia que as partes eram livres para contratar, e eram iguais, sem qualquer distinção de informação, conhecimento e poder de cada uma. A atuação do magistrado, frente a uma relação de consumo, pode e deve ser mais dinâmica, pretendendo assegurar a igualdade das partes ao mesmo plano jurídico." (Ementa da APC 197278518, 21르C, Des. Francisco José Moesch, TJ/RS, j. 17.06.1998).

Destaque-se que o legislador alemão, ao reformar o seu Código Civil de $1893 \mathrm{em}$ 2002 , incluiu uma nova norma de interpretação no $\$ 241$ do BGB, aplicável aos contratos de consumo (novo $\$ 13 \mathrm{c} / \mathrm{c} \$ 241$ e $\$ 242$ ), que é a seguinte: " $\$ 241$-Deveres oriundos das relaçôes obrigacionais- (1)... (2) As relaçôes obrigacionais podem, de acordo com seu conteúdo (tipo), obrigar cada uma das partes a ter em conta os direitos, as coisas/patrimônioe os interesses da outra parte. ${ }^{35}$ Note-se a beleza desta linha que amplia a visualização da relação, não só faz 'aparecer' os deveres anexos ao contrato, como ajuda a valorar as práticas comerciais do fornecedor. "Ter em conta os direitos...e os interesses da outra parte" é visualizar o 'alter' e valorar a conduta-conforme a boa-fé- daquele contratante mais forte, tanto na formaçáo do contrato (cláusula abusiva), quanto na execução do contrato (prática comercial abusiva).

Como ensina o próprio STJ, a própria cobrança é uma prática a ser valorada conforme a boa-fé e a confiança despertada: "É abusiva a prática de incluir na apólice um valor, sobre o qual o segurado paga o prêmio, e pretender indenizá-lo por um valor menor, correspondente ao preço de mercado, estipulado pela própria seguradora." ${ }^{36}$ Nesta visão de totalidade da relação de consumo é difícil dizer o que é prática complexa comercial, o que é cláusula autorizadora desta prática abusiva; o importante é visualizar que a boa-fé é o paradigma valorativo de todo o contexto contratual e de sua interpretação. Repita-se : a interpretação é sempre conforme a boa-fé, dos contratos de consumo (Art. $47 \mathrm{c} / \mathrm{c}$ Art. 4, III do CDC) e também nos contratos regulados pelo novo CCBR./2002 (Art. 113 do CCBR./2002).

b) função de controle e de limitação das condutas (Schrankenfunktion), pois o princípio, de forma imanente, está a limitar as "posiçōes” jurídicas dos contraentes e o exercício de seus direitos, dai, por exemplo, a proibição de cláusulas e práticas abusivas (Art. 39 e 51 do CDC). Como afirmamos, a boa-fé objetiva é um standard, um parâmetro

\footnotetext{
${ }^{35}$ No original: "§ 241. Pflichten aus dem Schuldverhältnis. (1)...(2) Das Schuldverhältnis kann nach seinem Inhalt jedn Teil zur Rücksicht auf die Rechte, Rechstgüter und Interessen des anderen Teils verpflichten."

${ }^{36}$ Ementa do Resp. 159.154/MG, DJ 22.06.98, Min. Ruy Rosado de Aguiar, e do Resp. 191.189/MG, j. 05.12.2000, DJ 05.03.2001, Min. Waldemar Zveiter e dos Embargos de Divergência. em Resp. 176.890/MG.
} 
Boa-fé nos serviços bancários, financeiros, de crédito e securitários e o Código de

Defesa do Consumidor

objetivo, genérico, um patamar geral de atuação, do homem médio, do bom pai de família que agiria de maneira normal e razoável naquela situação analisada. ${ }^{37}$ O julgador valora a atuação, decidindo se esta ultrapassou ou não a razoabilidade, os limites impostos por esta boa-fé objetiva qualificada, que é a de consumo. Abusiva é a conduta ou a cláusula que viola a boa-fé, os deveres impostos pela boa-fé aos agentes na sociedade, como ensina o STJ, no Resp. 219184/RJ, j. 26.10.1999, Min. Ruy Rosado de Aguiar:

"SERASA. Dano moral. - A inscrição do nome da contratante na Serasa depois de proposta ação para revisar o modo irregular pelo qual o banco estava cumprindo o contrato de financiamento, ação que acabou sendo julgada procedente, constitui exercício indevido do direito e enseja indenização pelo grave dano moral que decorre da inscrição em cadastro de inadimplentes. Recurso conhecido e provido."

Em outras palavras, é durante aquele exercício de interpretação conforme a boa-fé, de concreção que o magistrado irá identificar os limites à liberdade contratual; isto é, quais as cláusulas que ferem a boa-fé, ${ }^{38}$ cláusulas nulas e abusivas, ${ }^{39}$ que por isso não poderão ser consideradas, cláusulas que não pertencem ao "pacto" (pacta), cláusulas que violam o Direito e não poderão (sunt) ser "servidas" (servanda) ou ter qualquer eficácia, nem por vontade das partes, nem por decisão do juiz, uma vez que ofendem a ordem pública (art. $1^{\mathrm{o}}$ do CDC)..$^{40}$ Como ensina a Corte Federal Alemã $(\mathrm{BGH}):$ :O contratante é obrigado segundo a boa-fé, já na elaboração das condições gerais contratuais levar em conta de forma razoável os interesses de seu futuro co-contratante. Se ele concretiza

\footnotetext{
${ }^{37}$ Neste sentido, veja-se exemplar decisão do Min. Carlos Alberto Menezes Direito, in Resp. 158.728-RJ, 16.03.1999, cuja ementa ensina: "Plano de saúde. Limite temporal da intemação. Cláusula abusiva. 2. O consumidor não é senhor do prazo de sua recuperaçāo, que, como é curial, depende de muitos fatores, que nem mesmo os médicos são capazes de controlar. Se a enfermidade está coberta pelo seguro, nāo é possível, sob pena de grave abuso, impor ao segurado que se retire da unidade de tratamento intensivo, com o risco severo de morte, porque está fora do limite temporal estabelecido em uma determinada cláusula. Não pode a estipulação contratual ofender o princípio da razoabilidade, e se o faz, comete abusividade vedada pelo art. 51, IV, do Código de Defesa do Consumidor. Anote-se que a regra protetiva, expressamente, refere-se a uma desvantagem exagerada do consumidor e, ainda, a obrigações incompatíveis com a boa-fé e a eqüidade."

${ }^{38}$ Belo exemplo é o Resp. 251.024/SP, j. 27.11.2000, DJ 04.02.2002, em que o Relator, Min. Sálvio de Figueiredo, ensina a interpretação segundo 'os fins sociais da lei': "Direito Civil e do consumidor. Plano de saúde. Limitaçāo temporal de internação. Cláusula abusiva. CDC. Art. 51-IV. Uniformização interpretativa... I - É abusiva, nos termos da lei (CDC, Art. 51-IV), a cláusula prevista em contrato de seguro-saúde que limita o tempo de internação do segurado. II - Tem-se por abusiva a cláusula, no caso, notadamente em face da impossibilidade de previsão do tempo de cura, da irrazoabilidade da suspensão do tratamento indispensável, da vedação de restmgr-se em contrato direitos fundamentais e da regra de sobredireito, contida no art. $5^{\circ}$ da Lei de Introdução ao Código Civil, segundo a qual, na aplicação da lei, o juiz deve atender aos fins sociais a que ela se dirige e às exigências do bem comum."

${ }^{39}$ Assim também FERREIRA DA SILVA, Luis Renato, Revisão dos contratos: do Código Civil ao código do Consumidor, Forense, Rio de Janeiro, 1998, p. 52.

40 Assim, veja por todos, as decisões do TJ/RS, in AGI 70002602415, j. 21.06.2001, Des. João Armando Bezerra Campos, em cujo voto lê-se: "A existência de disposiçōes negociais abusivas contrárias às normas do Código de Defesa do Consumidor e ao princípio da boa-fé objetiva demonstra a atuação do credor contrário ao direito, a produzir a invalidade jurídica das obrigações excessivas e a ineficácia das parcelas acessórias, das quais decorrem sua inexigibilidade e inimputabilidade ao devedor." (p. 7 do original) e na APC 70001052885 , j. 19.10.2000, Rel. Des. João Armando Bezerra Campos, 14" Câm. Cível, cuja ementa é: "Invalidade das cláusulas negociais abusivas à luz do CDC e do princípio da boa-fé-objetiva. Reconhecida a abusividade das disposições negociais que estabeleceram as parcelas acessórias do débito, em violaçāo ao regime do CDC e ao princípio da boa-fé objetiva, merecem revisāo judicial."
} 
no texto contratual apenas seus interesses, então viola a liberdade contratual (Vertragsfreiheit). Consequentemente, a sua liberdade contratual fica limitada pelo princípio da boa-fé ( $\$ 242$ $B G B) . " 41$

c) funçã̉o de correção e de adaptação em caso de mudança das circunstâncias (Korrekturfunktion), a permitir que o julgador adapte e modifique o conteúdos dos contratos para que o vínculo permaneça (manutenção do vínculo) apesar da quebra da base objetiva do negócio, por exemplo, com a desvalorização do dólar em contratos de leasing, ${ }^{42}$ ou imponha deveres de renegociação ${ }^{43}$ face à quebra subjetiva da base do negócio, por exemplo, quando o consumidor perde seu emprego. A decisão aqui é casuística, como ensina o STJ, neste Resp. 200.019/SP j. 17.05.2001, DJ 27.08.2001, Min. Ari Pargendler:

"Civil. Promessa de compra e venda. Rescisão. Ação de rescisão de compromisso de compra e venda ajuizada pelo promitente comprador que ficou sem condições de cumprir o contrato. Procedência do pedido, à vista das circunstâncias do caso concreto.. " 44

d) função de autorização para a decisão por equidade (Ermächtigungsfunktion), pois como cláusula geral sua concreção passa pela ativa participação do julgador e não pode escapar à tópica e à procura da equidade contratual, originando assim um direito de equidade (Billigkeitsrecht) adaptado à sociedade e às necessidades atuais. Como relembra Hattenhauer, ${ }^{45}$ a fórmula "boa-fé" exige uma concretização no caso concreto, logo, casuística e com base na equidade (Billigkeit).

\section{A cláusula geral de boa-fé no CDC e as funçóes optimalizadas da boa-fé}

\footnotetext{
${ }^{41}$ No original, citado por BURCKHARDT, p. 19 (BGH, NJW 1965, 246): "Er ist daher nach Treu und Glauben verpflichtet, schon bei der Abfassung der allgemeinen Geschäftsbedingungen die Interess en seiner künftingen Vertragspartner angemessen zu berücksichtigen. Bringt er nur seine eigenen Interessen zur Geltung, so missbraucht er die Vertragsfreiheit. Insoweit ist die Vertragsfreiheit durch $\S 242$ BGB eingeschr

änkt."

42 Veja, por todos, Resp. 361.694/RS, j. 26.02.2002, Min. Nancy Andrighi, DJ 25.03.2002.

${ }^{43}$ A doutrina atual está estudando fortemente os deveres de renegociação, tanto na Alemanha (Norbert Horn, Jürgen Baur, Herbert Kronke, Ersnt Steindorff, Gabrielle Fecht, Andreas Nelle etc.), na Itália (Giovanni de Cristofaro, Giuseppe Gandolfi, Franco Anelli, todos sobre cessão dos contratos), nos Estados Unidos (seja nos teóricos da Lw and Economics -renegotiation-, seja nos internacionalistas, em virtude dos Principios da UNIDROIT para os contratos internacionais de 1994), assim relata em detalhes MARTINEK, Michael, "Die Lehre von de NeuverhandlungspflichtenBestandaufnahme, Kritik...und Ablehnung", in Archiv für die civilistische Praxis (AcP), 198 (1998), p. 330 a 398.

${ }^{44}$ Neste caso o STJ permitiu ao devedor (inadimplente), que perdera seu emprego, requerer a rescis ão do contrato, que não aproveitou e a devolução das parcelas pagas, mesmo se a outra parte se opunha, citando como precedentes os Resp. 132.903-SP, Min. Ruy Rosado de Aguiar, DJ 19/12/97, Resp. 109.960-RSP, Min. Ruy Rosado de Aguiar, DJ 24/03/97, Resp. 79.489-DF, Min. Ruy Rosado de Aguiar, DJ 22/04/97 e o já citado in Resp. 109.331-SP, DJ 31/03/97.

${ }^{45}$ HATTENHAUER, Hans, Grundbegriffe des Bürgerlichen Rechts, Beck, Munique, 1982, p. 93.
} 
Boa-fé nos serviços bancários, financeiros, de crédito e securitários e o Código de Defesa do Consumidor

Apresentadas as funções optimalizadas da boa-fé, como as entendem hoje os autores germânicos, cabe agora aprofundar um pouco mais este estudo. Assi, esta última função (de autorização para a decisão por equidade) depende diretamente do fato de aceitar-se ou não a existência no CDC de uma cláusula geral de boa-fé nas relações de consumo. Particularmente, considero que a boa-fé, no CDC, é princípio geral (Art. 4,III), é conceito indeterminado (art. 51 caput e IV) e é cláusula geral (art. 51,IV). Como ensina Antônio Junqueira de Azevedo, "a boa-fé é um conceito indeterminado", mas quando "se refere ao tipo de comportamento exigido - por exemplo, dos contratantesconfigura-se em cláusula geral." 46

A afirmação do grande mestre da USP é importante, pois o Art. 51, IV do CDC ("estabeleçam obrigações consideradas iníquas, abusivas, que coloquem o consumidor em desvantagem exagerada, ou sejam incompatíveis com a boa-fé ou a eqüidade"), apesar de seu texto conter conceitos indeterminados ${ }^{47}$ ('iníquas", "abusivas", "desvantagem exagerada", "boa-fé" e "equidade") e de seu caput ("Art. 51 . São nulas de pleno direito, entre outras, as cláusulas contratuais relativas ao fornecimento de produtos e serviços que: ...IV...") conter uma conseqüência, qual seja a "nulidade" da cláusula, exerce a função de cláusula geral de boa-fé no sistema do CDC. E, como cláusula geral permite a concreção pelo juiz do que é a boa-fé. Assim, é paradigma de valoração do juiz e é o paradigma de conduta, que deve ter sido violado, para que haja a reação do direito, seja a reação prevista no caput do Art. 51, a nulidade absoluta, seja as outras previstas nos Artigos 6, 28, 39, 46 e 54 do CDC, que oscilam entre ineficácia, desconsideração e modificação de cláusulas, em um juízo casuístico de equidade, conforme o contexto do caso concreto.

Em outras palavras, a cláusula geral de boa-fé do CDC está no inciso IV do Art. 51 , nos seus conceitos indeterminados, "boa-fé”, “equidade”, "desvantagem excessiva”, e não somente no caput do Art. 51 combinado com o inciso IV, a exemplo do que ocorreu no $\S 9^{\circ}$ da Lei alemã de 1976- AGBG ou do $\S 138$ do BGB, Código Civil Alemão. ${ }^{48}$ A cláusula geral pode ser formada por um conceito indeterminado, que indica uma solução exata para o juiz, mas mesmo assim este juiz é um personagem ativo do sistema e tem que concretizar a cláusula geral, por exemplo, concretizar a cláusula geral da boa-fé em um contrato bancário, financeiro, de crédito e securitário, mesmo que a conseqüência jurídica seja sempre a nulidade da cláusula (art. 51, caput e IV do CDC).

\footnotetext{
${ }^{46}$ AZEVEDO, Antônio Junqueira, "O princípio da boa-fé nos contratos", in Revista do Centro de Estudos judiciário, Brasília/CJF, 1999, set/dez, v. 9, p. 41.

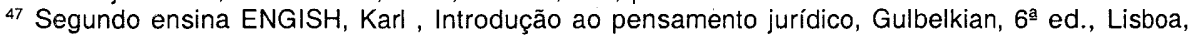
1988, p. 208:"Por conceito indeterminado entendemos um conceito cujo conteúdo e extensão são em larga medida incertos.".

${ }^{48}$ Assim conclui Karl ENGISH, p. 232, afirmando que "nem todo conceito indeterminado, normativo ou discricionário é já uma cláusula geral”, mas que o importante é o seu Tatbestand, p. 233: "Aquele que voluntariamente põe em perigo a vida duma pessoa", como cláusula geral do fazer-perigar (Gefährdungs-Generalklausel)."
} 
Já Nelson Nery Jr. afirma que a característica dos conceitos legais indeterminados seria que nestes "a solução já está preestabelecida na própria norma legal, competindo ao juiz apenas aplicar a norma, sem exercer nenhuma função criadora", ${ }^{49}$ e que as cláusulas gerais distinguem-se dos conceitos indeterminados "pela finalidade e eficácia", ao permitirem ao juiz: " preencher os claros com valores designados para aquele caso, para que se lhe dê a solução que ao juiz parecer mais correta, ou seja, concretizando os princípios gerais do direito e dando aos conceitos legais indeterminados uma determinabilidade pela função que têm de exercer naquele caso concreto". ${ }^{50}$ Pareceme que esta segunda afirmação, choca-se com a afirmação anterior. $\mathrm{O}$ grande consumerista brasileiro afirma que, em se tratando de conceitos indeterminados, o juiz ao aplicá-lo não exerceria "nenhuma função criadora". ${ }^{51}$

Data maxima venia, a este grande estudioso do direito alemão, a afirmação é ampla em demasia e poderia ser mal interpretada. Parece-me, ao contrário, que se a previsão de conseqüência jurídica serve para determinar o conceito indeterminado, sua presença em uma norma não tem o condão de excluir a possibilidade desta ser também uma cláusula geral e nem retira do juiz toda a função ativa de preencher o conceito indeterminado, valorando-o (Werturteil), concretizando-o, se tiver "finalidade" de cláusula geral. Engish ${ }^{52}$ esclarece que: “..., as cláusulas gerais não possuem, do ponto de vista metodológico, qualquer estrutura própria. Elas não exigem processos de pensamento diferentes daqueles que são pedidos pelos conceitos indeterminados, os normativos e os discricionários." Zippelius ${ }^{53}$ arremata que, em se tratando de conceitos que em si expressam valores, como "bons costumes" ("guten Sitten") e "boa-fé" ("Treu und Glauben"), o Spielraum do juiz sempre é grande e não há outra maneira de atuar, do que ativamente, aproximando-se lentamente do significado destas expressóes a determinar. ${ }^{54}$

O próprio Karl Larenz coloca entre as atividades de valoração criativa do juiz o preenchimento (Ausfüllung) dos conceitos indeterminados e concorda que um conceito indeterminado (citando expressamente inclusive a boa-fé e os bons costumes) pode ser também uma cláusula geral. ${ }^{55}$ Sendo assim, não se pode afirmar que uma norma contendo um conceito indeterminado (como o Art. 51,IV do CDC, o $\$ 138$ ou o $\$ 826$ do BGB), por indicar a nulidade ( $\$ 138$ do BGB) ou a indenização ( $\$ 826$ do BGB) como sanção, jamais poderiam ser cláusula geral; ao contrário, a evolução da

\footnotetext{
${ }^{49}$ NERY/NERY, p. 5.

50 NERY/NERY, p.6.

${ }^{51}$ NERY/NERY, p. 5.

52 ENGISH, p. 233.

${ }^{53}$ ZIPPELIUS, Reinhold, Juristische Methodenlehre, Beck, Munique, 1990, p. 43 ( $(9$, ,II).

${ }^{54}$ No original, ZIPPELIUS, p. 43: "Bedeutungsspielraum...Besonders unscharf sind Bezeichnung, die eine Wertung ausdrücken, die es also z.B. untersagen, die "guten Sitten" oder "treu und Glauben" zu verletzen... Hier bleibt der Rechtsprechung dann oft nichts anders übrig, als schrittweise den Bedeutungsumfang der Gesetzwortes genauer zu bestimmen."

${ }^{55}$ LARENZ, Karl, Methodenlehre der Rechstwissenschaft, 6.ed, Springer Verlag, Berlin, 1991, p. 288 e 289, “d) Werturteile".
} 
Boa-fé nos serviços bancários, financeiros, de crédito e securitários e o Código de Defesa do Consumidor

jurisprudência comprovou, que, muitas vezes, são as mais importantes e eficientes das cláusulas gerais!

O tema é interessante e podemos aprofundar a discussão. Como ensina Karl Engish, ${ }^{56}$ a parte inicial, a hipótese legal (Tatbestand) de uma norma pode conter uma cláusula geral (como o inciso IV do Art. 51), por decisão de técnica legislativa, ${ }^{57}$ utilizando-se justamente de conceitos indeterminados e, assim afirma o mestre alemão: "O verdadeiro significado das cláusulas gerais reside no domínio da técnica legislativa. Graças à sua generalidade, elas tornam possível sujeitar um mais vasto grupo de situações, de modo ilacunar e compossibilidade de ajustamento, a uma conseqüência jurídica."

Concordam também Karl Larenz e Claus-Wilhem Canaris, em sua obra de 1994, que estudando a versão do $\S 704-I$ do Primeiro Projeto de BGB ("Se alguém, por sua negligência ou dolo, realiza um ato ilícito ...que causa dano a outrem...fica obrigado a reparar os danos dai oriundos") concluem que esta norma era, em verdade, uma "grande" cláusula geral (grosse deliktsrechtliche Generalklausel) ${ }^{58}$ e que o atual $\S 823$ e $\$ 826$ possuem três "pequenas" cláusulas gerais (System von drei Kleinen" Generalklauseln), ${ }^{59}$ pois as expressões ou conceitos ("fahrlässigen rechtswidrigen Verletzung"/\$823,I; “Schutzgesetz"/\$823II e "Sittenwidrigkeit"/\$ 826 do BGB) necessitam a concretização pelo juiz (konkretizierungsbedürfig).

Note-se que aqui, mais uma vez, a solução, a reação jurídica, está prevista na conseqüência legal: indenização. Assim também Laren $z^{60}$ considera que o $§ 138$ do BGB é uma cláusula geral de observância dos bons costumes ("gute Sitten") e este artigo prevê expressamente a nulidade dos negócios jurídicos que violem os bons costumes: "Ein Rechstgeschäft, das gegen dieguten Sitten verstosst, ist nichtig." (Um negócio jurídico, que é contra os bons costumes, é nulo). ${ }^{61}$

Em outras palavras, os que os mestres germânicos afirmam é que uma norma pode ser, na sua hipótese legal (Tatbestand) ou em parte, uma cláusula geral (conceito multi-significativo, para a concreção do juiz) ${ }^{62} \mathrm{e}$ ao mesmo tempo ser um conceito indeterminado, pois traz uma solução fechada (nulidade, por ex., a de bons costumes do $\S 138$ do BGB) ${ }^{63}$ ou aberta (indenização, por exemplo, a do $§ 826$ do BGB) ${ }^{64}$ Larenz, em sua obra sobre Método, expressamente inclui a boa-fé e os bons costumes

\footnotetext{
${ }^{56}$ ENGISH, p. 233.

57 Assim também concentra-se no Tatbestand, para conceituar cláusula geral, CREIFELDS, Carl et allii, Rechstwörterbuch, Beck, Munique, 1994, p. 479

${ }^{58}$ No original, LARENZ/CANARIS, p.354 ( $(75,1)$ : "Hat jemand durch eine aus Vorsatz oder Fahrlässigkeit begangene"

${ }^{59}$ LARENZ/CANARIS, p. $355(\$ 75, \mathrm{I})$.

${ }^{60}$ LARENZ, Methoden, p. 289.

61 JAUERNIGNOLKOMMER, p. 88 e 89 (Rdn 1 e 2, § 138 do BGB)

${ }_{62}$ Assim expressamente, ENGISH, p. 228, explicando a diferença entre uma hipótese legal casuística e uma cláusula geral na hipótese legal.

${ }^{63}$ Exemplo de ENGISH, p. 231, usando porém a norma do § 826 do BGB.

${ }^{64}$ Exemplo de ENGISH, p. 231.
} 
como medidas que necessitam sempre de valoração concretizante ("konkretisierenden 'ausfüllungsbedürftigen' Masstab'). ${ }^{65}$

Há, pois que se evoluir daquela visão inicial de que o $\$ 242$ do BGB seria o modelo de cláusula geral (visão clássica, pois esta norma não prevê um resultado, aberto ou fechado, apenas informa a diretriz do juiz e dos indivíduos), para uma visão atualizada, visão determinada pelas decisóes dos anos 80-90, sobre fiança (Bürgschaft), da Corte Constitucional Alemã (BVerfG), ${ }^{66}$ que valoriza as novas cláusulas gerais ("pequenas", se assim as quiserem chamar), como a cláusula geral dos bons costumes do $\$ 138$ do BGB (que prevê a solução de nulidade-fechada-dos negócios jurídicos) ou as de proteção nos contratos de adesão ( $\$ 9^{\circ}$ da AGBGesetz de 1976). Também estas cláusulas gerais devem ser preenchidas com os direitos humanos ou fundamentais presentes nas Constituições: proteção dos mais fracos, em especial os consumidores (Art. 5,XXXII), proteção à privacidade, direito à informação (art. 5, XXXII e LXXI), só para citar alguns.

Note-se que, na versão reformada do BGB-Código Civil Alemão, que entrará em vigor em janeiro de 2003 , a cláusula geral do $\$ 9^{\circ}$ da lei de $1976, A G B G$ foi totalmente transcrita no $\$ 307$ (1) do BGB-Reformado, mas houve modificação de seu nome, a norma agora se denomina: "controle de conteúdo" (Inhaltskontrolle) ${ }^{67}$ e não mais cláusula geral (Generalklausel) como na lei de 1976, pois o $\$ 307$ (2) e 3) incorporou o mandamento de transparência do antigo $§ 8$ da AGBGesetz.

O importante é que, incorporada a lista de cláusulas abusivas no BGBReformado, a cláusula geral de boa-fé nos contratos de adesão do $§ 307$ (1) do BGB, aproxima-se assim ainda mais de nosso art. 51, IV do CDC (cláusula geral de boa-fé nos contratos com consumidores). Isto está a demonstrar, que náo importa o nome, $o$ local onde se encontra a norma (em uma lista de cláusulas abusivas ou dentre do Código Civil), ou a indicação de uma conseqüência, o que importa para autorizar uma cláusula geral é a técnica de sua hipótese legal (Tabestand) e a função desta norma no sistema: autorizando a função concretizadora e criadora dos juizes (Richterrecht) !

Concluindo, parece-me que o Art. 51, IV do CDC é a clausula geral de boa-fé nos contratos entre fornecedores e consumidores, inclusive os contratos bancários, financeiros, de crédito e securitários, a concretizar o princípio geral da boa-fé e equilibrio destas relaçōes (Art.4,III do CDC), pode ela alcançar as 4 funções da boa-fé comentadas por Jauernig e Volkommer também no sistema do CDC.

\footnotetext{
${ }^{65}$ LARENZ, Methoden, p. 288.

${ }^{66} \mathrm{Veja}$ as principais decisões de 1989, in REINICKE, Dietrich e TIDTKE, Klaus, Burgschaftsrecht, Luchterhand, Berlin, 1995, p. 60 (Rdn. 132).

${ }^{67}$ DAUNER-LIEB, Barbara et alii, BGB-Textausgabe-Mit neuem Schuldrecht, Deutscher Anwalt Verlag, Bonn, 2002, p. 73.
} 
Boa-fé nos serviços bancários, financeiros, de crédito e securitários e o Código de Defesa do Consumidor

II- Deveres de boa-fé potencializada no CDC: informação, transparência, cooperação e renegociação nestes contratos financeiros

Interessante repetir como a jurisprudência brasileira tem-se bem utilizado da cláusula geral de boa-fé, introduzida expressamente pelo CDC. De 1991 a 2001, a jurisprudência do TJ/RS apresenta 3.030 decisões a utilizar o princípio da boa-fé. ${ }^{68} \mathrm{Em}$ 1991, quando da entrada em vigor do CDC, foram apenas 5 (cinco) decisóes envolvendo a boa-fé (subjetiva-2 e objetiva-3), e em 2001 já eram 72 (setenta e duas), de janeiro a agosto, sendo que 55 citando expressamente os princípios e normas do CDC, dentre os quais se destaca, como os mais citado em conjunto com a boa-fé, o princípio da função social do contrato (em 16 destes casos) e da eqüidade contratual (os mesmos 16 casos), e sendo que, em 17 casos, não foi dado ganho de causa aos consumidores e nos demais 38 casos obtiveram os consumidores a decisão favorável.

Examinando-se esta rica e bela jurisprudência do TJ/RS, observa-se que muitos destes casos envolvem contratos bancários, financeiros , de crédito e securitários, onde a boa-fé objetiva foi utilizada para impor deveres anexos, como o dever de informar (A) previamente ao consumidor, o dever de cooperação (B), especialmente em contratos envolvendo seguros, ${ }^{69}$ dever de lealdade na correção das quantias, ${ }^{70}$ dever de cuidado na cobrança de dívidas ${ }^{71}$. Da mesma forma, a boa-fé é utilizada como limite a determinar o abuso, em especial a invalidade das cláusulas em contratos

${ }^{68}$ Agradeço a pesquisa exaustiva, cópia dos acórdãos e eleaboração das estatísticas aos integrantes de meu grupo de pesquisa CNPq/UFRGS, em especial à acadêmica Marilia Zanchet e à advogada Karen Moliterno. A pesquisa foi realizada de 02.04 .91 a 24.08.2001, aparecendo também outras 237 decisões com o termo boa fé sem hífen. Este universo de decisões não trata apenas de consumo, mas também de direito empresarial, posse, obrigaçōes familiares e outras, do universo foram retiradas para pesquisa apenas as decisões envolvendo consumo de 1991 (ano de entrada em vigor do CDC) e 2001 até 24 de agosto, em um total de 77 decisões, 5 decisões de 1991 e 72 de 2001 . Completada a pesquisa até 31.12 .2001 , chegou-se ao número de 3.030 decisões de boa-fé com hífen.

69 Veja interessante caso, onde antes da Lei de Planos de Saúde/96, seguradora de saúde queria punir com a reabertura das carências para internaçāo hospitalar indivíduo que no dia do pagamento estava hospitalizado em Hospital conveniado e, por isso, deixou de pagar no dia, adimplindo tão logo recebeu alta. A partir do dia do vencimento da parcela não "paga", a seguradora negou-se a cobrir seus gastos médicos, alegando que "terceiro" deveria ter pago em dia e que o doente deveria ter se preocupado com o pagamento... na convalescência... O relator Des. Loureiro Ferreira afastou a incidência de tal cláusula sob o argumento de força maior e ausência de culpa do consumidor (Ap. 592088512, TJRS, 3.a Câmara, j. 30.9.92), mas a consciência do dever de conduta conforme a boafé, ou do dever contratual anexo de cooperação na execução das obrigações poderia também ter evitado a lide.

${ }^{70}$ Bom exemplo é a El 70.002.028.298, j. 23.03.2001, Des. Rubem Duarte, cuja ementa é: "CRT. Aquisição de ações...Caracterizada a inexistência da lealdade contratual. Necessidade de preservação do princípio da boa-té ante a inexistência de cláusula prevendo a correção do capital integralizado. Diferença deferida com base no IGP-M." Observe-se que o relator não considera relação de consumo, pois o beneficiário do contrato é pequena lancheira.

71 Veja, por todas, a decisão no AG 70.002.771.475, j. 08.06.2001, Des. Aymoré Roque Pottes de Mello, cuja ementa é: "Ação revisional de contrato de arrendamento mercantil. Inscrição do nome do devedor fiduciante no CADIN, SERASA, SPC e assemelhados. llegitimidade do registro.

Configura constrangimento indevido e ato de objetiva retaliação e abusividade a inscrição do nome do devedor fiduciário em órgãos de inadimplentes (SERASA, CADIN, SPC e assemelhados), quando o débito que a motiva é objeto de impugnação judicializada..." 
bancários e de consórcios ${ }^{72}$ e de cartōes de crédito, ${ }^{73}$ controlando em geral os juros remuneratórios. ${ }^{74}$

Das funções do princípio da boa-fé objetiva, porém, a mais utilizada é a função interpretadora, com expressa menção ao Art. 47 do CDC, como norma concretizadora do princípio ${ }^{75}$ e norma que esclarece a conexidade entre o negócio principal de consumo e os negócios acessórios, que até comerciais podem ser. ${ }^{76}$ Observa-se igualmente que a jurisprudência exige um grau mais alta e qualificado de conduta segundo a boa-fé quando se trata de contrato de adesão de consumo. ${ }^{77}$

Este impressionante exercício de concretização de uma cláusula geral e de realização do Direito dos Juizes (Richterrecht) leva-nos a conclusão que andou muito bem o legislador do CDC ao confiar no Judiciário brasileiro e incluir de forma expressa o princípio da boa-fé e do equilíbrio contratual. ${ }^{78}$ Vejamos, pois, dois deveres de conduta diretamente oriundos da boa-fé (informação e cooperação) e seus possíveis reflexos.

${ }_{72}$ Assim APC 70000289116, j. 22.05.2001, Des. Ney Wiedemann Neto, cuja ementa é: "Consórcio de veiculo. Revisão de contrato... Incidência do CDC. É típica relação de consumo estado sob a égide da legislação protetiva do consumidor o contrato firmado entre as partes. Taxa de Administração. Percentual máximo e base de cálculo. Nula de pleno direito cláusula contratual que prevê taxa de administração de $47,58 \%$, estabelecendo obrigação abusiva, incompativel com a boa-fé e a equidade. No contrato de consórcio criado por sociedade mercantil para a aquisição de bens de seu comércio ou fabrico (veículos automotores), a taxa de administração a ser cobrada pela administradora não pode ultrapassar o percentual máximo de $5 \%$, calculada sobre o preço do bem."

${ }^{73}$ Veja ementa: "Negócios jurídicos bancários. Contrato de cartão de credito. Ação de revisão contratual. Aplicação do CDC. Figurando de um lado a administradora/contratada, ora apelante - que capta recursos no mercado financeiro para saldar os débitos relativos a produtos e serviços adquiridos e utilizados pelo contratante, e de outro, o cliente/ contratante - que em contrapartida paga a anuidade cobrada pela administradora - estabelecese cristalina relação de consumo. Falta do contrato nos autos. Incidência do CDC. Inversão do ônus da prova. Configurada a relação de consumo, com a aplicação do CDC deve-se operar a inversão do ônus da prova em favor do autor hipossuficiente. Tendo o autor requerido a juntada do contrato pelo banco, não ha falar em carência de ação por falta de documentos necessários a instruçāo da inicial. (APC 70002197762, Des. André Luiz Planella Villarinho,j. 08/03/2001) TJ/Rs.

${ }^{74}$ Interessante observar esta linha da jurisprudência gaúcha que não mais utiliza a fonte constitucional, mas o $\mathrm{CDC}$ e as noçōes de boa-fé e equidade contratual para determinar o abuso na cobrança de juros, assim ensinando o voto: "As regras do art. $6^{\circ}$, V e art. $51, \mathrm{IV}$, e $\S 1 \%$, III , do CDC inviabilizama fixação de juros no patamar de $9,1 \%$ a.m., como verificado no caso concreto, por configurar-se em cobrança iniqua, de vantagem exagerada, incompativel com a boa-fé e equidade, e excessivamente onerosa ao consumidor" APC 70001754480, j. 14.03.2001, Des. Roque Miguel Frank, ementa: "Direito econômico. Contratos bancários. Revisão dos contratos em aberto. Possibilidade. Juros. Aplicação do CDC. Comissāo de Permanência...Em face dos dispositivos contidos nos arts. 60 e 51 do $\mathrm{CDC}$, as cláusulas contratuais não podem se constituir como prestaçōes desproporcionais, que estabeleçam obrigações iniquas, de modo a se tomarem excessivamente onerosas ao devedor. A violação ao principio da eqüidade contratual impōe a nulidade da cláusula."

${ }_{75}$ Veja, como exemplo, a ApC. 70000633487, j. 28.05.2001, Des. Matilde Chabar Maia, em cuja ementa lê-se: "Ação de cobrança. Subscrição de açōes. CRT. Interpretação das cláusulas contratuais da maneira mais favorável ao consumidor. Boa-fé negocial." Observe-se que a relatora não considerou relação de consumo, mas há utilização do Art. 47 do CDC.

${ }^{76}$ Neste sentido exemplar a APC 70001780022, j. 22.02.2001, Des. Luiz Ary Vessini de Lima, em que em contrato assinado com a CRT anteriormente à entrada em vigor do CDC para conseguir uma linha telefônica o consumidor tinha que ser passar a ser "acionista" da Companhia: "É evidente que, à época do contrato ora tratado, a aquisição da linha estava vinculada a das ações, esta de natureza obrigatória, o que agora está modificado, não se podendo falar, todavia, em prevalência da visão societária, já que, mesmo nesta, haveria de prevalecer o princípio geral da boa-fé objetiva, máxime diante da vinculação acima salientada, com aquisição de serviço nitidamente de consumo, já protegido pelo Direito, muito embora ainda não vigente o atual Código de defesa do Consumidor" ( $p .8$ do voto). 77 Exemplar é a decisão na APC 599439296, j. 28.03.2001, Des. Lúcia de Castroi Boller: "CRT. Subscrição de açōes... Tratando-se de contrato de adesão e inexistindo regra contratual no tocante à hipótese de variação do preço, o contrato deve ser interpretado de forma favorável ao aderente, aplicando-se o princípio da boa-fé."

${ }^{78}$ Assim concorda Tepedino, Direito Civil-Constitucional, p.12. 
Boa-fé nos serviços bancários, financeiros, de crédito e securitários e o Código de Defesa do Consumidor

A. Uma boa-fé protetora unilateral: informação e transparência a favor dos consumidores

Repita-se que a boa-fé serve de paradigma de conduta e pardigma de valoração da conduta das partes, sendo, pois, por sua natureza, bilateral (art.4,III in fine). No $\mathrm{CDC}$, pela sua própria ratio deste Código tutelar dos consumidores (art. $5, \mathrm{XXXII}$ da $\mathrm{CF} / 88$ e Art. $48 \mathrm{ADCT}$ ), a boa-fé aparece com funções mais protetoras e, por determinação legal, unilaterais. Como já afirmamos, a ratio legis do Código de Defesa do Consumidor foi justamente de valorizar este momento de formação do contrato de consumo (1) e visualizar o contrato e todas as condutas dos fornecedores como uma totalidade no tempo (2).

A tendência atual é,pois, a de examinar a "qualidade" da vontade manifestada pelo contratante mais fraco, mais do que a sua simples manifestação: somente a vontade racional, a vontade realmente livre (autônoma) ${ }^{79} \mathrm{e}$ informada, ${ }^{80}$ legitima, ${ }^{81}$ isto é, tem o poder de ditar a formação e, por conseqüência, os efeitos dos contratos entre consumidor e fornecedor. A tendência atual é também a de examinar a conduta negocial do fornecedor, valorando-a e controlando-a, dependendo da conduta (abusiva ou não) a formação do vínculo (informaçōes prévias, acesso ao contrato, envio de mercadorias não requeridas etc.) ${ }^{82} \mathrm{e}$ a interpretação de quais as obrigações, as quais o consumidor está vinculado (cláusulas, promessas dos vendedores, prospectos, publicidades, sites etc.).

\footnotetext{
${ }_{79}$ Neste sentido, veja decisão do STJ, in Resp. 95.625-MG, DJ 09.06.1997, Min. Waldemar Zweiter, cuja ementa ensina:"Processual Civil - Ação cautelar - Letra de Câmbio -Contrato consigo mesmo ... II - O princípio, assim, consubstanciado no verbete 60 , do STJ e revigorado pelo legislador que, com a vigência do Código do consumidor, passou a coibir cláusulas, cuja pactuação importe no cerceio da livre manifestação da vontade do consumidor."

${ }^{80}$ Veja-se exemplo do TJ/RS, caso envolvendo seguro-saúde: "Não se compreende que num contrato como o que assinam os segurados da Golden Cross, não são esclarecidos estes pontos importantes que dizem respeito a abrangência das exclusões de cobertura....(APC no 598427227, Quinta CC, TJRS, Des. Carlos Alberto Bencke, j. 08/04/1999). E no STJ: "É ilegal a transferência de risco da atividade financeira, no mercado de capitais, próprio das instituições de crédito, ao consumidor, ainda mais que não observado o seu direito de informação (art. 6, III, e 10, "caput", 31 e 52 do CDC). "(Resp. 268661-RJ, Rel. Min. Nancy Andrighi, j. 16/08/ 2001).

${ }_{81}$ Neste sentido, veja decisão do STJ, in RESP 296453/RS, Min. Carlos Alberto Menezes Direito ,j. 05/06/ 2001, cuja ementa é: "Compra e venda de bem imóvel assinada e paga antes do contrato definanciamento entre a construtora e o banco, mediante garantia hipotecária. Ausência de consentimento dos promitentes compradores. Cláusula que institui mandato para esse fim considerada abusiva, a teor do art. 51, VIII, do Código de Defesa do Consumidor. 1. Considerando o Acórdão recorrido que o bem foi comprado e integralmente pago antes do contrato de financiamento com garantia hipotecária, que os adquirentes não autorizaram a constituição de tal gravame, que sequer o mandato foi exercido e, ainda, que é abusiva a cláusula que institui o mandato, a teor do art. 51, VIII, do Código de Defesa do Consumidor, não existe afronta a nenhum dispositivo sobre a higidez da hipoteca, presente a peculiaridade do cenário descrito."

${ }_{82}$ Neste sentido destaque-se a Portaria no 001 , de 15 de março de 2001, do Secretário de Direito Econômico do Ministério da Justiça, que em seu Art.1, estabelece como abusiva a cláusula que, violando este dever póscontratual de cooperar:" informar: 1. estipule presunção de conhecimento por parte do consumidor de fatos novos não previstos em contrato informar: "1. estipule presunção de conhecimento por parte do consumidor de fatos novos não previstos em contrato." e " 8 . considere, nos contratos bancários, financeiros e de cartōes de crédito, o silêncio do consumidor, pessoa física, como aceitação tácita dos valores cobrados, das informaçães prestadas nos extratos ou aceitação de modificaçōes de índices ou de quaisquer alterações contratuais."
} 
1. O dever de informar e a transparência nos contratos bancários, financeiros, de crédito e securiários

OCDC, expressamente, face ao déficit informativo típico dos consumidores, ${ }^{83}$ impōs os deveres de boa-fé apenas para o fornecedor: é este agente econômico que deve informare é este agente que responde pelas falhas e defeitos da informação, nas fases pré e pós-contratual e contratual (ex viartigos 8, 9, 10, 12, 14, 18, 20, 30, 31, 33, 34, 35,40,43, 46, 48, 52, 54 do CDC). Note-se a unilteralidade da lei tutelar, que impóe deveres ao fornecedor e assegura direitos aos consumidores, uma vez que ao consumidor é assegurado um direito de "liberdade de escolha" (art. 6,II in fine), de informação (Art. 6, III) e de proteção contra abusos informativos (art. 6,IV). Em matéria de serviços bancários, de crédito e financeiros o CDC impóe ao fornecedor um dever de informar qualificado, que aqui será denominado de "dever de transparência", inspirado no Transparenzgebot do direito alemão.

Em resumo, o Código de Defesa do Consumidor tem como fim justamente reequilibrar as relaçōes de consumo, harmonizando e dando maior transparência às relações contratuais no mercado brasileiro (art. 4.o do CDC).$^{84}$ Para alcançar este equilibrio de forças nas relaçōes contratuais atuais, o CDC opta por regular também alguns aspectos da formação do contrato, impondo novos deveres para o elaborador do texto (fornecedor) e assegurando novos direitos para o consumidor (aderente) quando da formação das relações contratuais de consumo (art. 6.o, II, III e IV), dentre eles o direito de livre escolha e o seu instrumental direito de informação.

O dever de informar (Informationspflicht) foi imposto aos fornecedores pelos arts. 6,III, $8,10,12,14,18,20,30,31,33,34,35,46,51,52$ e 54 do CDC. Sobre o tema há que se mencionar que o dever de informar já é visualizado na fase pré-contratual, fase de tratativas entre o consumidor e o fornecedor, quando o consumidor escolhe, de forma livre (Art. 6, II

\footnotetext{
${ }^{83}$ Sobre déficit informacional veja FRADERA, Vera, "O Dever de Informar do Fabricante", in RT 656/53-71.

${ }^{84}$ Assim ensina o TJ/RS: "Negócio jurídico bancário...Violação de princípios. Prevalece atualmente o princípio da relatividade do contrato, como forma de assegurar o equilíbrio da relação contratual, mediante a concretização de preceitos tais como o da liberdade e igualdade entre as partes e da boa-fé ." (APC 70000454934, Des. André Luiz Villarno, j. 27.03.2001
} 
Boa-fé nos serviços bancários, financeiros, de crédito e securitários e o Código de Defesa do Consumidor

do CDC), racional e informada (Art. 6, $\mathrm{Wl}$ do CDC), ${ }^{85}$ por exemplo, o financiamento ou leasing do carro que pretende adquirir, ou qual o seguro de vida ou o plano de saúde deverá proteger sua familia pelos próximos anos, tipo, quais são as carências e as exclusões da cada tipo de plano etc. ${ }^{86}$ Aqui as informações são fundamentais para a decisão do consumidor (qualidade, garantias, riscos, carências, exclusōes de responsabilidade, existência de assistência técnica no Brasil etc. $)^{87}$ e não deve haver indução ao erro, ${ }^{88}$ qualquer dolo ou falha na informação por parte do fornecedor ou promessas vazias, ${ }^{89}$ uma vez que as informações prestadas passam a ser juridicamente relevantes, integram a relação contratual futura e, portanto, deverão depois ser cumpridas na fase de execução do contrato, positivando a antiga noção da proibição do venire contra factumproprium. ${ }^{90}$

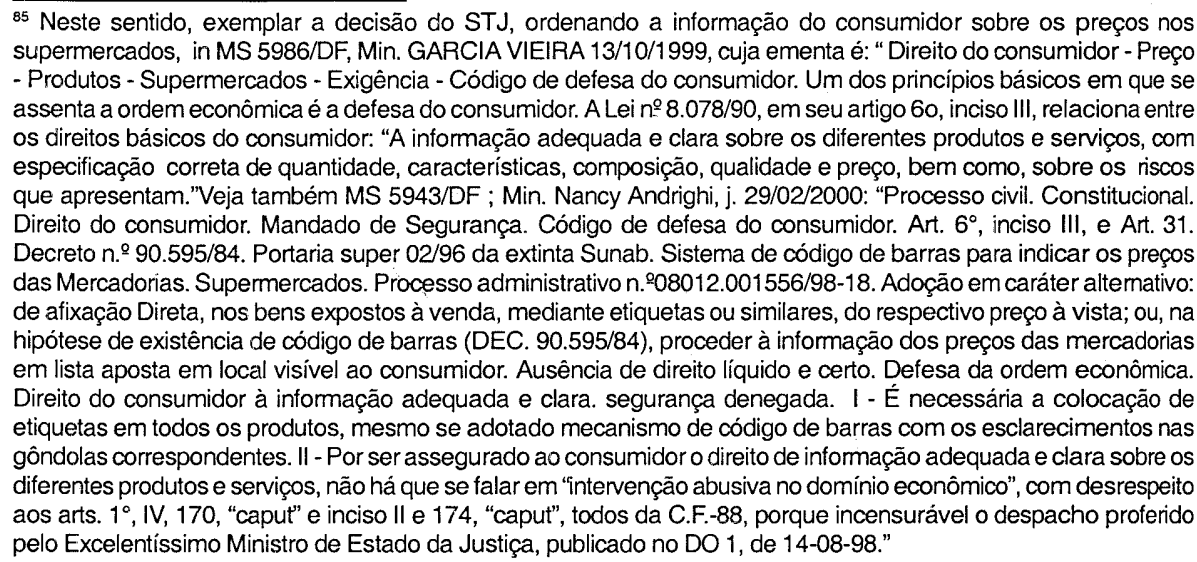
${ }^{86}$ Neste sentido a decisão do TJ/RS, cuja ementa é: "Civil. Seguro-saúde... A ausência de explicação conceitual, ao nivel do homo medius, do verdadeiro significado de doença crônica, tambem conduz a iniquidade da cláusula e a torna abusiva. não se compreende que num contrato como o que assinam os segurados da ..., não são esclarecidos estes pontos importantes que dizem respeito a abrangência das exclusōes de cobertura. A inespecificidade e a falta de conceito tornam a cláusula passivel de anulabilidade, a teor do art.115 do Código civil. Tal dispositivo encontra redação mais clara e moderna no artigo 51, inciso IV, do Código de Defesa do Consumidor, mas ambos buscam praticamente o mesmo escopo, que e o de proteger uma das partes da relação contratual contra o arbítrio da outra. Apelo provido. (APC n 598427227, TJRS, Relator: Des. Carlos Alberto Bencke, julgado em 08/04/1999)

${ }^{87}$ Assim TJ/RS, APC 597095827, Des. Antônio Guilherme Tanger Jardim, j. 26/06/1997:"Contrato de compra e venda de título de uso de instalaçōes hoteleiras ("time sharing"). Método abusivo de venda. Descumprimento do dever de informar. Nulidade do contrato. Litigância de má-fé inexistente. É nulo o contrato resultante de método agressivo de venda, pelo qual, o consumidor e atraído a um local preparado e submetido a pressão psicológica para assiná-to, sem que possa se inteirar do alcance de suas cláusulas. A litigância de má-fé diz respeito a má-fé processual, não à utilizada quando da contratação."

${ }^{88}$ Veja decisão do TJ/RS: "Contrato...Time-sharing...Artigos 6o, IV, 37, 46 e 53 do Código de Defesa do Consumidor. Demonstrado que o contrato particular de promessa de compra e venda de fração ideal foi firmado diante do induzimento em erro do comprador, diante de falsa promessa ou omissão sobre dificuldades, agravada pela forte pressão exercida quando da assinatura da avença por propaganda exagerada e apelativa,... (APC 70001471523, 17르. CC, Des. Elaine Harzheim Macedo, j. 03/10/2000).

${ }^{89}$ Assim o TJ/RS: "Agravo de instrumento. Ação coletiva de consumo. Antecipação de tutela. Decisāo confirmada. $O$ fato de ter sido dado destaque em suas embalagens, invólucro, ou, mesmo anúncio, a palavra "natural" pode gerar nos consumidores a falsa idéia de que o produto e natural, de que seus componentes são naturais, justificando a concessão da liminar..."(AGI no 70001147586, Des. João Pedro Freire, j. 07/03/2001)

${ }^{\circ}$ LARENZ, pp. 26, 27, 28. 
Na fase pré-contratual, no momento de tomada de decisão pelo consumidor, também deve ser dada a oportunidade do consumidor conhecer o conteúdo do contrato (expressamente art. 46 do $\mathrm{CDC}$ ), de entender a extensão das obrigações que assume e a abrangência das obrigaçóes da prestadora de serviços, dai a importância do destaque e clareza das cláusulas contratuais (Art. $54 \mathrm{do} \mathrm{CDC}$ ) ${ }^{91}$ É a nova transparência obrigatória nas relações de consumo (art. 30, 33, 34 e 48 do CDC), em que vige um novo dever de informar (art. 30, 31, 12, 14, 18 e 20 do CDC), imputado ao fornecedor de serviços e produtos, e uma nova relevância jurídica da publicidade, instituída pelo CDC como forma de proteger a confiança despertada por este método de marketing nos consumidores brasileiros.

Esta inversão de papéis, isto é, a imposição pelo CDC ao fornecedor do dever de informar sobre o produto ou serviço que oferece (suas características, seus riscos, sua qualidade) e sobre o contrato que vinculará o consumidor, inverteu a regra do "caveat emptor" (que ordenava ao consumidor uma atitude ativa: se quer saber detalhes sobre o plano de saúde, informe-se, descubra o contrato registrado em cartório no Rio de Janeiro ou São Paulo... atue ou nada poderá alegar...) para a regra do "caveat vendictor" (que ordena ao vendedor ou corretor de planos de saúde que informe sobre o conteúdo desse, riscos, exclusões, limitações etc.). Estabeleceu-se, assim, um novo patamar de conduta, de respeito no mercado, que não admite mais sequer o dolus bonus do vendedor, do atendente, do representante autônomo dos fornecedores, face ao dever legal. Este dever legal de atuação conforme à boa-fé sempre que o fornecedor realiza ato negocial visando atrair consumidores como clientes e criando expectativas legítimas é reconhecido pelo Superior Tribunal de Justiça. ${ }^{92}$

Interessante repetir que a doutrina estrangeira visualiza dois tipos de deveres de informação, o primeiro denominado dever de "conselho" ou aconselhamento, e o segundo, dever de esclarecimento simples. O dever de esclarecimento (Aufklarungspflicht, em alemão) obriga o fornecedor do serviço informar sobre a forma de utilização e a qualidade dos serviços .Em resumo, hoje o contrato é informação, dai a importância de sua interpretação semprea favor do contratante mais fraco e das expectativas legítimas nele criadas por aquele tipo de contrato. Neste momento, o elaborador do contrato e aquele que o utiliza no mercado de consumo, o fornecedor, devem ter em conta o seu dever próprio de informar, que inclui o

\footnotetext{
${ }^{91}$ Assim ensina o Superior Tribunal de Justiça: "Seguro-saúde. Limite temporal de internação. Cláusula limitativa. Redação com destaque....- Vulnera a lei a decisão que considera válida cláusula limitativa de obrigação da estipulante, inserida no contrato sem destaque (art. 54, par. 4ำ do CDC).Recurso conhecido e provido."(in Recurso Especial 21.423-7-RJ, j. 02.08.2001, Rel. Min. Ruy Rosado de Aguiar).

${ }^{92}$ Veja ementa: 'Seguro de assistência médico-hospitalar - Plano de assistência integral (cobertura total)', Assim nominado no Contrato. - As expressōes 'assistência integral' e 'cobertura total' são expressões que têm significado unívoco na compreensão comum, e não podem ser referidas num contrato de seguro, esvaziadas do seu conteúdo próprio, sem que isso afronte o princípio da boa-fé nos negócios. Recurso especial não conhecido. (in Recurso Especial 26.456-2-SE, j. 13.08.2001, Rel. Min. Ari Pargendler)
} 
Boa-fé nos serviços bancários, financeiros, de crédito e securitários e o Código de Defesa do Consumidor

dever de redação clara e com destaque, além do dever de considerar a condição leiga do outro, evitando dubiedades na redação contratual..$^{93}$

Para que o homo medius entenda as obrigações que está assumindo, dai a importância de sancionar a prática de não destacar as cláusulas limitativas dos direitos dos consumidores, como esta fazendo o STJ, ${ }^{94}$ pois não destacar as cláusulas é não informar corretamente, o que coloca o fornecedor em violação contratual (art. 54, (4) $^{\circ}$ ).

O dever de informar foi, pois, imposto ao fornecedor e o aplicador da lei deve interpretar toda a relação contratual (publicidade, promessas, pré-contratos, prospectos, contrato, silêncios, adendos, práticas e cláusulas etc) sempre a favor do consumidor (Art. 47 do CDC), para só após definir se houve abuso ou não. ${ }^{95}$

2. Um dever de informar durante toda a execução dos contratos bancários, financeiros, de crédito e securiários

No V Congresso Brasileiro de Direito do Consumidor, Belo Horizonte, 2 de maio de 2000, no painel referente ao Direito Básico à Informação, a conclusão nr. 3 foi aprovada por unanimidade e ensina expressamente :"Os deveres de Informação nos contratos de prestaçãode serviços aplicam-se nas fases pré-contratual, contratual e pós-contratual."

Assim, na fase pós-contratual, face aos riscos descobertos posteriormente à prestação principal nos produtos e serviços, há necessidade de alerta, de informação da massa de consumidores (e do recall impostos pelo CDC), ${ }^{96}$ da mesma forma, a

\footnotetext{
${ }^{93}$ Assim decidiu, sobre o dever de redação clara e com destaque, o Superior Tribunal de Justiça: "Direito Civil. Contrato de seguro-saúde. Transplante. Cobertura do tratamento. Cláusula dúbia e mal redigida. Interpretação favorável ao consumidor. Art. 54, $\S 4^{\circ}, \mathrm{CDC}$. Recurso Especial. Súmula/STJ, Enunciado 5. Precedentes. Recurso não-conhecido....II - Acolhida a premissa de que a cláusula excludente seria dúbia e de duvidosa clareza, sua interpretação deve favorecer o segurado, nos termos do art. $54, \S 4^{\circ}$ do Código de Defesa do Consumidor. Com efeito, nos contratos de adesão, as cláusulas limitativas ao direito do consumidor contratante deverão ser redigidas com clareza e destaque, para que não fujam de sua percepção leiga." (in Recurso Especial 31.150-9-SP, j. 25.06.2001, Rel. Min. Sálvio de Figueiredo Teixeira)

${ }^{94}$ Veja decisão já citada, Resp 214237/RJ, Min. Ruy Rosado de Aguiar j. 02/08/2001, "Seguro-saúde. Limite temporal de internação. Cláusula limitativa. Redação com destaque. - A Segunda Seção decidiu ser nula a cláusula limitativa do período de internação hospitalar do segurado (Art. 51 do CDC). - Vulnera a lei a decisão que considera válida cláusula limitativa de obrigaçāo da estipulante, inserida no contrato sem destaque (art. 54 , par. 4을 do CDC). Recurso conhecido e provido."

95 "Ação Monitória - Cartão De Crédito - Cobrança - Saldo Devedor - Cláusula Contratual - Alteração

- Cartão de crédito. Cobrança de saldo devedor. Principal não contestado. Inconformismo limitado aos encargos da dívida. Ausência de comprovação pela Administradora do atendimento ao disposto nos artigos 46, 52 e 54 do Código de Defesa do Consumidor, ou seja, que tenha previamente à celebração do acordo informado ao consumidor sobre os parâmetros das bases contratuais, permitindo-lhe entender de forma adequada o negócio pactuado." TJRJ - AC 2.622/98 - Reg. 220998 - Cód. 98.001 .02622 - RJ - 14a C.Cív. - Rel Juíza Maria Henriqueta Lobo - J. 30.06.1998), in Revista Jurídica 267,jan/2000, ementário nr. 15653.

${ }_{96}$ Veja Art. 8 e seg. do CDC. Em levantamento realizado pelo Bolsista CNpQ/UFRGS Lucas Annes, nos 53 recalls realizados pelo Ministério da Justiça/SDE/ DPDC de 2000 a 2002, chama a atenção que $82 \%$ destes eram referentes à veículos (carros, microônibus, motos etc.), os outros eram referentes a remédios, computadores, pneus e eletrodomésticos (máquina de lavar, ar condicionado, televisores). Frisamos aqui a importância deste dever de informar/vigiar e recolher/consertar para prevenir danos coletivos ao consumidores, veja , por todos, o Caso Corsa/Tigra, in RDC 40/288-298, este recall por defeito nos cintos de segurança iniciou com vítima fatal em Belo Horizonte e outros 25 acidentes e chegou a conclusão que o cinto de segurança de mais de um milhão de veículos (1.062.737) poderia se soltar em colisões acima de $50 \mathrm{~km} / \mathrm{h}$.
} 
maneira de atual massificada de cobrança de dívidas através de bancos de informação ${ }^{97}$ demonstra a importância de manter-se o fluxo informacional do fornecedor ${ }^{98}$ para com o consumidor (dever de aviso de abertura de cadastro, imposto pelo CDC), uma vez que com esta técnica massificada o déficit informativo entre o consumidor-leigo e o fornecedor-profisisonal aumenta. ${ }^{99}$ Nos contratos cativos de longa duração, ${ }^{100}$ como nos contratos bancários e de cartão de crédito ${ }^{101}$ por exemplo, quando os contatos com prepostos, as informações por meios eletrônicos e em caixas eletrônicos e as informações parciais através de extratos multiplicam-se, é que deve ser de "boa-fé" a conduta do fornecedor, cumprimento seus renovados deveres de informar corretamente os consumidores. ${ }^{102}$

${ }_{97} \mathrm{O}$ uso dos bancos de dados para cobrar dívidas aumenta a defasagem informativa entre 0 consumidor e o fornecedor, dai o dever de aviso que o CDC impõe ao fornecedor, quando da abertura destes cadastros negativos. Veja, exemplar, a decisāo do STJ, in Resp 292045/RJ, Min. Carlos Alberto Menezes Direito, 27/08/2001, cuja ementa ensina: "Dano moral. Cadastro negativo. Art. 73 do Código de Defesa doConsumidor. 1. Nāo tem força a argumentação que pretende impor ao devedor que quita a sua dívida o dever de solicitar seja cancelado o cadastro negativo. $O$ dispositivo do Código de Defesa do Consumidor configura como prática infrativa "Deixar de corrigir imediatamente informação sobre o consumidor constante de cadastro, banco de dados, fichas ou registros que sabe ou deveria saber ser inexata". Quitada a dívida, sabe o credor que nāo mais é exata a anotação que providenciou, cabendo-Ihe, imediatamente, cancelá-la."

${ }_{98}$ Neste sentido destaque-se a Portaria no 001, de 15 de março de 2001, do Secretário de Direito Econômico do Ministério da Justiça, que em seu Art.1, estabelece como abusiva a cláusula que, violando este dever pós-contratual de cooperar: "6. autorize, em virtude de inadimplemento, o não fornecimento ao consumidor de informaçōes de posse do fornecedor, tais como: histórico escolar, registros médicos, e demais do gênero; “

${ }_{99}$ Neste sentido exemplar a decisāo, da Min. Fátima Nancy Andrighi, in Resp. 299501/MG, 11/09/ 2001, em cuja ementa é: " Revisão de contrato - Arrendamento mercantil (leasing) - Relação de consumo - Indexação em moeda estrangeira (dólar) - Crise cambial de janeiro de 1999 - Plano real. Aplicabilidade do art. 6 , inciso V do CDC - Onerosidade excessiva caracterizada. Boa-fé objetiva do consumidor e direito de informação. Necessidade de prova da captação de recurso financeiro proveniente do exterior. - É ilegal a transferência de risco da atividade financeira, no mercado de capitais, próprio das instituições de crédito, ao consumidor, ainda mais que nāo observado o seu direito de informação (art. $6^{\circ}$, III, e 10, "caput", 31 e 52 do CDC)."

${ }^{100}$ Veja o nosso Contratos,3.Ed., p.68ss.

101 Da mesma forma, no referido $V$ Congresso Brasileiro de Direito do Consumidor, 3 conclusões voltadas para os contratos relacionais, que perduram no tempo, devemos citar: "7. O princípio da informação adequada nos contratos relacionais de consumo envolve o dever de informar não apenas no momento da celebração contratual, mas durante todo o período da performance ou execução contratual. (aprovada por unanimidade) 8. O CDC (artigos $6^{\circ}$, incisos III e V; 20․, $2^{\circ} ; 31 ; 36 ; 37 ; 46$ e 66) constitui fundamento legal claro suficiente para obrigar a informação adequada ao consumidor nos contratos relacionais de consumo. (aprovada por unanimidade) 9 . $\dot{E}$ dever do fornecedor nos contratos relacionais de consumo manter o consumidor adequada e permanentemente informado sobre todos os aspectos da relação contratual, especialmente aqueles relacionados ao risco, qualidade do produto ou serviço ou qualquer outra circunstância relevante para a sua decisão de consumo, durante todo o período em que perdurar a relação contratual. (aprovada por unanimidade")."

${ }_{102}$ Assim, exemplar, é a decisão do Min. Ruy Rosado de Aguiar, mesmo em relação comercial, veja Resp 250.523/SP, 19/10/2000, cuja ementa ensina: "Conta corrente. Apropriação do saldo pelo banco credor. Numerário destinado ao pagamento de salários. Abuso de direito. Boa-fé. Age com abuso de direito e viola a boa-fé o banco que, invocando cláusula contratual constante do contrato de financiamento, cobra-se lançando mão do numerário depositado pela correntista em conta destinada ao pagamento dos salários de seus empregados, cujo numerário teria sido obtido junto ao BNDES. A cláusula que permite esse procedimento é mais abusiva do que a cláusula mandato, pois, enquanto esta autoriza apenas a constituição do título, aquela permite a cobrança pelos próprios meios do credor, nos valores e no momento por ele escolhidos. Recurso conhecido e provido." 
Boa-fé nos serviços bancários, financeiros, de crédito e securitários e o Código de

Defesa do Consumidor

Realmente, hoje, face à complexidade das prestaçōes de serviços atuais, é na fase da execução contratual que o dever de informar, como fazer de boa-fé, como fazer de cooperação e lealdade, valoriza-se e torna-se realmente essencial para a harmonia de relações entre consumidor e fornecedor (Art. 4,III do CDC). Note-se que o dever de informar é, pois, "anexo" a toda a relação contratual, acompanhando-a do nascimento à morte total, não se esgotando na fase pré-contratual. ${ }^{103}$

Assim, manifestou-se a jurisprudência do STJ sobre os extratos bancários indecifráveis,: "As instituições financeiras jamais se preocupam em apresentar os cálculos de forma inteligível para os seus clientes. São siglas e mais siglas que consomem a atenção até mesmo daquelas pessoas mais habituadas ao trato financeiro, que, freqüentemente, não conseguem entender o conteúdo das demonstrações. É um desafio permanente ao homem médio decifrar os extratos bancários". ${ }^{104}$

Da mesma forma, se é direito do consumidor ser informado (Art. 6, III) este deve ser cumprido pelo fornecedor e não fraudado (art. 1 응 $\mathrm{CDC}$ ), assim a cláusula ou prática que considere o silêncio do consumidor como aceitação (a exemplo do Art. 111 do novo Código Civil), ${ }^{105}$ mesmo com falha da informação, não pode prevalecer (art. 24, 25), acarretando a nulidade da cláusula no sistema do CDC (Art. 51,I) e até mesmo no sistema geral do novo Código Civil (art. $424 \mathrm{CCBr} / 2002) .{ }^{106}$ Frise se que a obrigação de bem explicar o plano, o contrato, o preço, ${ }^{107}$ os extratos ${ }^{108}$ ou o uso do objeto é do fornecedor, assim como a obrigação de entregar cópia do contrato, cópia dos documentos contratuais, ${ }^{109}$ manter documento de cancelamento do

\footnotetext{
${ }^{103}$ Assim ensina AZEVEDO, Antônio Junqueira de, "Responsabilidade pré-contratual no Código de Defesa do Consumidor: estudo comparativo coma responsabilidade pré-contratual no direito comum", in Direito do Consumidor, 18 , p. 26 e 27.

${ }^{104}$ Resp. 234284-SP, Min. Carlos Alberto Menezes Direito, trecho citado in Revista Trimestral de Direito Civil, vol. 2, abr./jun. 2000, p. 297. Ementa: "Execução de cédula de crédito comercial. Demonstrativo de débito...2. É de comum sabença que as instituições financeiras apresentam extratos indecifráveis pelo homem médio, gerando, até mesmo, dificuldades para aqueles que habituados estāo ao sistema..."(Resp. 234.284/SP, Min. Carlos Alberto Menezes Direito, j. 02.05.2000, DJ 26.06.2000,p. 164)

${ }^{105}$ Assim o texto do CCBr./2002: "Art. 111. O silêncio importa anuência, quando as circunstâncias ou os usos o autorizarem, e não for necessária a declaração de vontade expressa."

${ }^{106}$ Assim o texto do CCBr./2002: "Art. 424. Nos Resp. 292.942, j. 03.04.2001, Rel. Min. Sálvio de Figueiredo Teixeira contratos de adesão, são nulas as cláusulas que estipulem a renúncia antecipada do aderente a direito resultante da natureza do negócio."

${ }_{107}$ Veja sobre o preço, o citado MS 5986/DF, Min. Garcia Vieira 13/10/1999 e quanto à interpretação a posteriori, decisão do TJ/RS, APC 599439296, j. 28.03.2001, Des. Lúcia de Castroi Boller: "CRT. Subscrição de ações...Tratando-se de contrato de adesão e inexistindo regra contratual no tocante à hipótese de variação do preço, o contrato deve ser interpretado de forma favorável ao aderente, aplicando-se o princípio da boa-fé."

${ }^{108}$ Assim Resp. 234.284/SP, Min. Carlos Alberto Menezes Direito, j. 02.05.2000, DJ 26.06.2000,p. 164.

${ }^{109}$ Assim decisão do TJ/RS, in APC 70001562370, j. 11.10.2000, Rel. Des. José Aquino Flores de Camargo, $20^{a}$ Câm. Civel, cuja ementa é: "Exibição de documentos. Documento comum às partes- art. 358,III, do CPC. Dever de lealdade e boa-fé inerente aos negócios jurídicos". E onde se lê:

"Não calha o argumento do réu no sentido de que teria entregue os documentos e estaria a cargo do autor a juntada deste. Trata-se de documentos comuns às partes, não podendo o banco se negar a fornecê-los, diante do dever de lealdade e boa-fé inerente aos negócios juridicos."
} 
contrato, ${ }^{110} \mathrm{e}$ informar o cancelamento da dívida aos bancos de dados, ${ }^{111}$ além da obrigação de preencher e ler bem os documentos contratuais (bancários). ${ }^{112}$

$\mathrm{O}$ dever de informar é do fornecedor ${ }^{113}$ e o aplicador da lei deve interpretar toda a relação contratual (publicidade, promessas, pré-contratos, prospectos, contrato, silêncios, adendos, práticas e cláusulas etc.) sempre a favor do consumidor, para só após definir se houve abuso ou não. ${ }^{114}$ Assim resume o STJ: “ II - O caráter de norma pública atribuído ao Código de Defesa do Consumidor derroga a liberdade contratual, para ajustá-la aos parâmetros da lei, impondo-se a redução da quantia a ser retida pela promitente vendedora a patamar razoável, ainda que a cláusula tenha sido celebrada de modo irretratável e irrevogável." 115

B) Dever de cooperação: entre um dever geral de renegociação e o superendividamento do consumidor

Define Leitão Marques, “...o sobreendividamento, também designado por falência ou insolvência de consumidores, refere-se às situaçóes em que o devedor se vê impossibilitado, de uma forma durável ou estrutural, de pagar o conjunto das suas dívidas, ou mesmo quando existe uma ameaça séria de que o não possa fazer no momento em que elas se tornem exigíveis." 116

\footnotetext{
${ }^{110}$ Assim decisão: "Código do consumidor. O CDC dá especial relevância à informação que o fornecedor de bens e serviços deve prestar ao consumidor (arts. 30,36,37 e 46). Em não fornecendo sequer uma via do contrato ou prova do pedido de cancelamento a administradora deixou de cumprir suas obrigaçōes legais, pelo que deve arrostar com os prejuizos decorrentes. Relapsia demonstrada com a cobrança de fatura relativa a gastos verificados após constar de seus assentamentos a nota de cancelamento do cartão. Foi indevida a negativação do consumidor no cadastro de inadimplentes pelo que deve suportar o ressarcimento dos danos morais. Recurso improvido." (Ap.Civ. 5389/98 Reg. 210898, 98.001.05389, TJ/RJ, 5Cciv, un., Des. José C. Figueiredo, j. 24/06/98)."

${ }^{111}$ Exemplar a decisão já citada do STJ, in Resp 292045/RJ, Min. Carlos Alberto Menezes Direito, 27/ $08 / 2001$.

${ }^{112}$ Assim decisão: "Dano Moral. Serviço bancário. Preenchimento do 'doc' por funcionário do banco.Omissão de dígito. Incumprimento do contrato. Cadastramento da consumidora no Bacen. Responsabilidade pelo fato do serviço. ...O preenchimento do documento de transferência interbancária por funcionário do banco, obriga-o a fazê-lo com diligência e transfere ao banco a responsabilidade por eventual acidente de consumo, ou seja, dano ocasionado ao consumidor pela exteriorização do vício de qualidade do serviço." (TJ/RS, Ap.C. 599 428.976, j. 17.11.1999, Des. Matilde Chabar Maia)."

${ }^{113}$ Veja decisão do TJRJ - AC 2.622/98 - Reg. 220998 - Cód. 98.001.02622 - RJ - 14a C.Cív. - Rela Juiza Maria Henriqueta Lobo - J. 30.06.1998), in Revista Jurídica 267,jan/2000, ementário nr. 15653.

114 A Portaria nr. 001/2001 do SDE/MJ bem esclarece a ligação entre a informação e a abusividade da cláusula (ou prática) afirmando a nulidade das cláusulas que: "1. estipule presunção de conhecimento por parte do consumidor de fatos novos não previstos em contrato." e "8. considere, nos contratos bancários, financeiros e de cartões de crédito, o silêncio do consumidor, pessoa física, como aceitação tácita dos valores cobrados, das informações prestadas nos extratos ou aceitação de modificações de índices ou de quaisquer alteraçōes contratuais."

${ }^{115}$ Resp. 292.942, j. 03.04.2001, Rel. Min. Sálvio de Figueiredo Teixeira.

${ }^{116}$ Leitão Marques, Manuel et allii, O endividamento dos consumidores, Lisboa, Almedina, 2000, p. 2.
} 
Boa-fé nos serviços bancários, financeiros , de crédito e securitários e o Código de Defesa do Consumidor

A doutrina européia, acompanhando a objetivação das condutas e fugindo da idéia de culpa subjetiva contratual, tende a superar a diferença entre fatos subjetivos e objetivos supervenientes e prefere hoje analisar o inadimplemento do consumidor de boa-fé ou o superendividamento como sendo 'activo' ou 'passivo'. Assim ensina Leitão Marques: "O sobreendividamento pode ser activo, se o devedor contribui activamente para se colocar em situação de impossibilidade de pagamento...; ou passivo, quando circunstâncias não previsíveis (desemprego, precarização do emprego, divórcio, doença ou morte de um familiar, acidente, etc.) afectam gravemente a capacidade de reembolso do devedor, colocando-o em situação de impossibilidade de cumprimento." (grifos dos autores). ${ }^{117}$

Este é um tema considerado quase "tabu" pelas Instituições financeiras e Administradoras de Cartões de Crédito, face à grande insolvência dos consumidores no Brasil. ${ }^{118}$ A verdade é que nas sociedades de consumo consolidadas, o tema do superendividamento é tratado como problema jurídico que é, legislaçōes especiais são preparadas para evitar (prevenção) e dirimir este problema (tratamento), que faz parte do sistema das sociedades de consumo. ${ }^{119}$ Nestes países há sempre uma espécie de "falência civil" dos consumidores e suas famílias, a evitar a "morte" total do "homo economicus", afinal os contratos de consumo devem ser momentos de cooperação e lealdade e não de "destruição" e "falta de opçōes" do parceiro contratual mais fraco. ${ }^{120}$

O novo Código Civil Brasileiro, aprovado em 10 de janeiro de 2002, reforça esta tese da necessidade de se pensar seriamente no Brasil sobre superendividamento, pois ao unificar as obrigaçóes civis e comerciais e ao criar a figura do empresário, deixa ao direito do consumidor -direito especial-a proteção do contratante mais fraco nestas relaçóes mistas (entre civil-consumidor e comerciante-fornecedor). Assim, o privilégio da falência e concordata comercial não mais se sustenta, se em verdade o superendividamento é fenômeno que atinge ao consumidor-leigo e sua prevenção e tratamento deve fazer parte da proteção contratual deste sujeito vulnerável nas sociedades de consumo, não só no primeiro mundo.

\footnotetext{
117 Leitão Marques et alii, p. 2.

${ }^{118}$ Veja meu citado artigo de 1996 sobre crédito ao consumo, in RDC 17, p. 55 e 56, onde concluo também: "Constatamos que a lei não menciona aspectos importantes para as relações de crédito, como a imposição de um prazo de reflexão especial, ou a declaração expressa do vínculo entre o contrato de consumo principal e o contrato acessório de crédito, assim como um regime especial para o super endividamento e para a exigência de garantias pessoais superiores as possiveis para aquele determinado consumidor.

${ }^{119}$ Como ensina Paisant, Gilles, "El tratamiento del sobreendeudamiento de los consumidores en derecho frances", in RDC 41: "...el problema del sobreendeudamiento es un fenómeno económico y social duradero en nuestras sociedades occidentales."

120 Veja sobre o modelo norte-americano e o canadense, os estudos dé José Reinaldo de Lima Lopes, Crédito ao consumo e superendividamento - Uma problemática geral, in R. Inf. legisl., 129 (1996), p. 109-115 e in RDC 17, p. 57 e seg.
} 
A França trata o superendividamento com bastante eficiência. ${ }^{121}$ Como ensina Danielle Khayat, existem dois tipos de bancos de dados sobre endividamento dos consumidores, os bancos positivos e os bancos negativos, e dois tipos de tratamento do superendividamento, pelo direito civil geral e por leis especiais. ${ }^{122}$ Aqui os países principais de direito comparado são a França, a Alemanha, os Países Baixos, os Estados Unidos e o Reino Unido, que conhecessem a falência civil (ou bankruptcy) ou procedimentos assemelhados, que conduzem (a exceção da Alemanha) ao desaparecimento de toda ou em parte da dívida do particular após a liquidação de seus bens, com participação judicial ou acordo supervisionado pelo juiz para o reescalonamento da divida, redução do montante, diminuição dos juros etc. ${ }^{123}$

A lei especial francesa, de 31 de dezembro de 1989, define a situação de superendividamento como "caracterizada pela impossibilidade manifesta pelo devedor de boa-fé de fazer face ao conjunto de suas dívidas não profissionais exigíveis e não pagas". ${ }^{124}$ Como ensina o mestre Gilles Paisant, o direito do superendividamento francês também conheceu evolução lenta, com normas mais processuais e administrativas, ${ }^{125}$ e hoje se encontra no Título III do Code de la Consommation. ${ }^{126}$ Mister destacar a fonte material do direito do consumidor de prevenção e tratamento do superendividamento, uma vez que a premissa da legislação especial é justamente estar o consumidor-devedor de boa-fé subjetiva e ser a dívida não-profissional. ${ }^{127}$ Gostaria de dividir minhas observaçóes em dois momentos, um versando sobre o uso dos linhamentos propostos pelos direitos humanos na concreção da cláusula geral da boa-fé (1), e um segundo, analisando o dever de cooperação dos parceiros contratuais para evitar o superendividamento do parceiro mais vulnerável, dever oriundo da boa-fé, tanto no Código de Defesa do Consumidor de 1990, como no novo Código Civil unificador das obrigações civis e comerciais, aprovado em 10 de janeiro de 2002.

\footnotetext{
${ }^{121}$ Assim ensina Paisant, in RDC 41: "En la Francia de hoy, nadie puede poner en duda la efectividad del dispositivo de tratamiento del sobreendeudamiento de los particulares. Desde la entrada en vigor de la primera ley específica el 1 de marzo de 1990 hasta el 31 de diciembre de 2000 se han registrado 1.027.841 demandas de consumidores para distrutar de sus ventajas. En 1998 hubo 117000 demandas, 142000 en 1999 y 148000 en 2000 (1). Como puede comprobarse, las demandas están creciendo. Este fenómeno es muy diversificado. Se puede estar sobreendeudado por 10000 F o 1,5 MF. El sobreendeudado puede ser un asalariado, obrero o mando, lo mismo que un funcionario; un soltero o un matrimonio y, a menudo, un parado o un individuo divorciado. En cualquier categoría profesional o personal se pueden encontrar sobreendeudados. No existe un perfil tipo de sobreendeudado.'

122 Khayat, Danielle, Le droit du suendettement des particuliers, LGDJ, Paris, 1997, p. 12 .

${ }^{123}$ Assim Khayat, p. 12 e 13.

${ }^{124}$ Assim Khayat, p. 11, no original: "Le législateur dut ainsi se résoudre à indiquer que la situation de surendettement est 'caracterisée par l'impossibilité manifeste pour le débiteur de boanne foi de faire face à l'ensemble de ses dettes non profissionnelles exigibles et à échoir'... "

125 Paisant, Gilles, "La réforme de la procédure de tratement du surendettement par la loi du 29 juillet 1998 relative à la lutte contre les exclusions", in RTDcom. 51 (4), oct.-déc.1998, p. 743.

126 Paisant, La réforme, p. 755.

${ }^{127}$ Sobre as premissas da legislação, veja KHAYAT, p. 11 e 12.
} 
Boa-fé nos serviços bancários, financeiros, de crédito e securitários e o Código de

Defesa do Consumidor

1) Direitos humanos do devedor na concreção das cláusulas boa-fé e bons costumes

Mister ter em conta os direitos humanos, os direitos fundamentais dos devedroes, pessoas físicas, quando da concreção das cláusulas gerais de boa-fé, probidade e bons costumes. Efetivamente, após as decisóes „,revolucionárias“ da Corte Constitucional alemã e da Corte Federal da Alemanha, ${ }^{128}$ a interpretação jurisprudencial destes novos limites à liberdade contratual em matéria de contratos bancários e de crédito estão na ordem do dia e constituem um dos temas atuais mais polêmicos em direito comparado. Sobre o tema escrevi: “...decisão de 1993 da Corte Constitucional Alemá (Bundesverfassungsgericht) ${ }^{129} \mathrm{em}$ matéria de controle das cláusulas de um contrato bancário impôs às Cortes inferiores a consideração do direito fundamental de desenvolvimento da personalidade (art.2,I da Grundgesetz), quando as cortes civis realizassem a concreção ou subsunsão do que seria contrário às cláusulas gerais de respeito aos bons costumes ( $\$ 138$ do BGB) e à boa-fé ( $\$ 242$ do BGB).

A novidade foi considerar contrária aos bons costumes uma exigência mais fictiva do que real, isto é, um aval por uma pessoa sem patrimônio, um filho estudante ou uma dona de casa, sem condições reais de pagar a dívida (muito superior as suas possibilidades atuais) e que necessitaria passar toda a sua vida a trabalhar para pagá-la, uma verdadeira dívida asfixiante se exigida no futuro. Para concretizar a cláusula geral do $§ 138$ e $\S 242$ do BGB, as Cortes deveriam, segundo a Corte Constitucional alemã, utilizar-se da noção de direitos fundamentais do indivíduo (no caso concreto um estudante de medicina de 21 anos, que serviu de avalista da dívida do pai, um pequeno comerciante) a desenvolver sua personalidade (desenvolvimento da personalidade econômica e social) no futuro. Como conseqüência este contrato de garantia deveria ser considerado contrário aos bons costumes e à boa-fé, logo ineficaz, uma vez que o garante não tinha nem patrimônio, nem trabalho e estava fazendo uma quase „,consignação" de seu futuro. A Corte Constitucional expressamente ordenou às cortes civis o controle do conteúdo dos contratos de crédito e contratos bancários, nos quais o contratante mais fraco é obrigado a suportar cargas anormais para suas condiçóes pessoas (superendividamento, no original, Überschuldung).

O mais interessante e revolucionário aqui é a proibição de um abuso frente a um terceiro (filho), que não é, nem será consumidor direito do crédito, e o efeito indireto dos direitos fundamentais em relações entre particulares (Drittwirkung). As instituições bancárias defenderam-se respondendo que o aval seria necessário para evitar a transferência de patrimônio entre pessoas da mesma família, mas a Corte não

\footnotetext{
${ }^{128}$ Veja decisão da Corte Constitucional Alemã de 19.10.1993, in: NJW BVerfG 1994, 36-39 e a obra de REINICKE, Dietrich e TIEDTKE, Klaus, Bürgschaftsrecht, Berlim, Luchterhand, 1995.

${ }^{129}$ BVerfG Beschl. v. 19.101993 - 1BvR 567/89 u.la., in: NJW 1994,36. A ementa original é a seguinte: „Die Zivilgerichte müssen - insbesondere bei der Konkretisierung und Anwendung von Generalklauseln wie $\S 138$ und $\S 242$ BGB - die grundrechtlcihe Gewährleistung der Privatautonomie in Art. 2,I GG beachten. Daraus ergibt sich ihre Pflicht zur Inhaltskontrole von Verträge, die einen der beiden Vertragspartner ungewöhnlich stark belasten und das Egbnis strukturell ungleicher Verhandlungsstärke sind.“
} 
modificou seu julgamento. A Corte Federal Alemá (BGH) conseguiu seguir um caminho próprio, proibindo o aval prestado pela esposa do comerciante como contrário às exigências de boa-fé e aos bons costumes, mas somente após o divorcio dos dois, quando não haveria mais o perigo da transferência de patrimônio entre eles. ${ }^{130}$

As decisões citadas examinam contratos de crédito entre profissionais, comerciante e banco, mas a reação da jurisprudência alemã destinavam-se a proteger o parceiro mais fraco nesta relação, o garantidor, filho, esposa e terceiro. Transposta esta tendência para os contratos de crédito ao consumidor que exigem iguais garantias, as conseqüências práticas seriam muitas e tenderiam a modificar as práticas hoje existente no mercado brasileiro. As decisōes alemãs representam, em minha opinião, um novo e inevitável momento do direito de proteção dos direitos fundamentais de primeira geração (Direitos políticos), unidos a defesa dos direitos fundamentais de segunda geração, como o da defesa do consumidor."

Se estas observaçōes já eram importantes em 1995/96, quanto mais agora que estamos prestes a assistir a entrada em vigor do novo Código Civil de 2002, com seus princípios de boafé, função social dos contratos, onerosidade excessiva e probidade. As conclusōes continuam válidas também no sistema tutelar do $\mathrm{CDC}$, ainda mais se agora com o CCBr./2002 até entre comerciantes serão válidas...

Resta então refletir se não haveria já, no Brasil, um dever de cooperar para evitar o superendividamento dos consumidores no Brasil?

2) O dever de cooperação para evitar o superendividamento dos consumidores em contratos cativos de longa duração (renegociação e atuação cooperativa)

Na quarta edição de meu livro sobre contratos, ${ }^{131}$ destaco que a doutrina européia atual manifesta-se pela necessidade de uma razoável equivalência de prestaçōes, face ao princípio da igualdade no direito privado. ${ }^{132} \mathrm{Em}$ especial, merece análise a tendência da doutrina alemã atual, que com base nos deveres de cooperação da boa-fé e na antiga exceção da ruína, está ativamente estudando a existência de um dever geral de renegociação nos contratos de longa duração. ${ }^{133}$

\footnotetext{
${ }^{130}$ Decisão de 05.01.95, IX ZR 85/94, Karlsruhe, in: WM (Frankfurt), n. 6, p.237s.

${ }_{131}$ Veja mais detalhes em nosso livro, Contratos,4.Edição, Revista dos Tribunais, 2002, no prelo.

132 Assim BERTHIAU, Denis, Le principe d'égalité et le droit civil des contrats, LGDJ, Paris, 1999, p. 429 :"...l'équivalence dans l'économie générale du contrat s'impose en définitive comme étant le point d'orgue de toute réflexion sur le principe d'égalité dans le droit civil des contrats, car s'il est évident aue l'exploitation de la faiblesse d'une partie contractante par l'autre doit juridiquement être traitée, il n'y a un intérêt à le faire que dans la mesure où l'équivalence dans l'économie généerale du contrat s'en trouve affectée. Prende une autre position conduit à mettre en péril les équilibre ontractuels, liés à la voluntée des parties, à l'utilité du contrat et à la nécessité de sa stabilité. ... En d'autres termes la manifestation unitaire du principe d'égalité dans le contrat devrait s'orienter vers la composante de l'équivalence des prestations, entendue largement comme l'équivalnece des droits et des obligations contractuels. "Veja também, KHAYAT, p. 10, a qual explica a importância de prevenir o super-endividamento na França.

${ }^{133}$ Veja o estudo de MARTINEK, Michael, "Die Lehre von de Neuverhandlungspflichten- Bestandaufnahme, Kritik...und Ablehnung", in Archiv für die civilistische Praxis, 198 (1998), p. 330 e seg. , o qual apesar de negar a existência deste dever geral de renegociação (Neuverhandlungspflicht) em todos os contratos de longa duração, concorda que a doutrina majoritária o identifica em muitíssimo deles, em especial os de longa duração de consumo, p. 356 e seg.
} 
Boa-fé nos serviços bancários, financeiros, de crédito e securitários e o Código de Defesa do Consumidor

Estes autores alemães partem da premissa de que haveria uma cláusula ou um dever de modificação de boa-fé (no caso brasileiro, com previsão expressa no Art. 6, V do CDC) dos contratos de longa duração, sempre que exista quebra da base objetiva do negócio (Wegfall der Geschäftsgrundlage) e onerosidade excessiva dai resultante. Assim, considera a parte majoritária da doutrina alemã, de que haveria uma espécie de dever ipso jure de Adaptação (ipsojureAnpassungspflicht) ${ }^{134}$ ou dever de antecipar e cooperar na adaptação, logo, dever (ou para alguns Obligenheit) ${ }^{135}$ de renegociar (Neuverhandlungspflicht) o contrato. ${ }^{136}$

Interessante é que a doutrina alemã vai buscar no Direito Comercial (na kxmercatoria dos princípios dos contratos internacionais do UNIDROIT e na teoria da LawandEconomics) a origem da aceitação deste dever, considerando usus comercial incluir tais cláusulas de readaptação nestes contratos, ${ }^{137}$ retirando dai a necessidade da lei incluir claramente este dever nos contratos civis, especialmente nos entre partes com forças de negociação diferentes (onde a inclusão da cláusula é improvável), como concretização atual da boa-fé. A base deste dever é, pois, em resumo o novo standard de boa-fé nas negociações e na execução dos contratos no tempo. Horn ${ }^{138}$ chega mesmo a sugerir a inclusão de um número 2 no famoso $\$ 242$ do $\mathrm{BGB}$, com o seguinte texto:

“\$242, Abs.2 BGB-Reformvorschlag-Se a prestação de uma das partes, em virtude de circunstâncias externas, se tornar excessivamente difícil, pode este contratante requerer uma razoável divisão dos prejuízos entre as duas partes através de adaptação do contrato, se ele não deveria contar com estas circunstâncias, em especial se este risco no sentido do contrato não lhe é normal e se a manutenção do contrato nas condições anteriores não lhe é razoável (zumutbar), podendo requerer também a rescisão do contrato. A adaptação (Anpassung) ou a rescisão (Auflösung) dar-se-á por consenso entre as partes ou por decisão judicial." 139

Se o $\$ 242$ não mudou, o novo BGB-Reformado em 2000 e 2001 traz agora um direito geral de rescisão em contratos cativos de longa duração (novo $\$ 314$ do BGB-Reformado), mesmo que este direto não esteja previsto, se considerando o caso concreto e levando em conta os interesses de continuidade do vínculo, não é razoável (zumutet) a continuidade para uma das partes, evitando assim o superendividamento. ${ }^{140}$ Mais ainda, o novo BGB-Reformado traz a figura da quebra da base do negócio (novo $§ 313$ ), permitindo a adaptação do vínculoà

\footnotetext{
${ }^{134}$ MARTINEK, pg. 363 e seg., relata que esta Teoria é majoritária na Alemanha.

135 Note-se que a 'Obligenheit' é um dever de boa-fé menos forte, tão reduzido, que se parece quase ao ônus, porém com sanções mais importantes, veja FABIAN, p. 53.

${ }^{136}$ MARTINEK, p. 367, relata esta teoria de Horn, Jürgen Bauer, Horst Eidemüller, Wolfgang Harms, Herbert Kronke, Karsten Schmidt e Ernst Steindorff.

${ }^{137}$ MARTINEK, p. 382 e seg.

${ }^{138}$ Assim relata MARTINEK, p. 369, informando que também o $\$ 315$ ganharia uma nova norma regulando os prazos de graça para esta renegociação ou adaptação, p. 369 e 370.

${ }_{139}$ Apud MARTINEK, , p. 369.

${ }^{140}$ Veja meu artigo "Código Civil alemão muda para incluir a figura do consumidor- Renasce o "direito civil geral e social" ? com Ulrich Wehner, in RDC 37, p. 271-278 e Dauner-Lieb, p. 81. Note-se que o novo §314 prevê perdas e danos, apesar da rescisão, mas evita que o consumidor "morra" atado em um contrato, como ocorre no SFH, onde se o credor nada lhe oferecer, não á saída para o comprador vulnerável e inadimplente (não consegue rescindir, nāo consegue vender, não consegue quitar, não consegue pagar, não consegue renegociar...não consegue seguir homo economicus).
} 
nova base e evitando o superendividamento. ${ }^{141}$ Note-se que, com base, no CDC, a jurisprudência brasileira conhece estas duas linhas.

No caso do leasing em dólar, ${ }^{142}$ a resposta jurisprudencial foi exemplar quanto à proteção do consumidor, mas dispare quanto aos fundamentos. A jurisprudência brasileira chegou mesmo a manifestar-se sobre a lesão enorme $\mathrm{e}^{143} \mathrm{e}$ pela possibilidade de modificação da cláusula de reajuste em dólar que criava onerosidade excessiva para os consumidores após a maxi-desvalorização da moeda brasileira (Art. 6,V do CDC). Muitos Tribunais optaram por permitir a rescisão contratual com base nas teorias da imprevisão, visualizando-as no $\mathrm{CDC}$, outros utilizaram-se do Art. 6,V, modificando a cláusula de reajuste do preço, ora substituindo-a por outros índices, ora reequilibrando a relação e o sinalagma funcional deste tipo de contrato, intimamente ligado aos juros do financiamento. ${ }^{144}$

O importante desta segunda linha de opiniōes, a qual me filio, é ter concretizado a cláusula geral do Art. 6,V, como introduzindo no ordenamento jurídico brasileiro a teoria da quebra da base objetiva do negócio, preconizada por Larenz. Neste sentido, não há necessidade de que o fato superveniente do Art. 6, V seja "imprevisível", "bastando a demonstraçâoobjetiva da excessiva onerosidade advinda para o consumidor" (Resp. 268661-RJ, Rel. Min. Nancy Andrighi, j. 16/08/2001). ${ }^{145}$

${ }_{141}$ Veja apresentação de Dauner-Lieb, p. 8 a 12.

${ }^{142}$ Note-se que outros negócios envolvendo crédito e financiamento, com nomes diversos, ocorrerão no mercado brasileiro na mesma época, tais como o contrato de "compra e venda [de automóvel] com assunção de dívida em moeda estrangeira", veja bela decisão do TA-/MG, in Direito do Consumidor, vol. 35, p. 329-338.

${ }^{143} \mathrm{O}$ exemplo mais interessante desta linha jurisprudencial de controle de preços é do TJ/RS, em que se identifica $91 \%$ de lucro bruto como lesionário: "Arrendamento mercantil. Rescisão. Lesão Enorme. Cautelar para devolução do bem. Reintegração de Posse. Ajuizada pelo arrendatário ação cautelar para devolução do bem, falece o arrendante interesse jurídico para aforar demanda reitegratória. Lucro bruto de $91 \%$ sobre o custo do bem, em leasing de 24 meses, consiste lesão enorme ao arrendatário (art. 6, V, CDC). Nulidade de cláusula. Rescisão do contrato, com a devolução do veículo e o perdimento pelo arrendatário das parcelas pagas. Apelo improvido. Unânime."

144 Veja decisão: "O Contrato de Arrendamento Mercantil ou Leasing pode ter modificadas as cláusulas que implicam em onerosidade excessiva ao consumidor, por fatos supervenientes à data da celebração do contrato, como as cláusulas que vinculam a correção das prestações e do valor residual à variação do dólar."( TJ-PARÁ, $2^{a}$ Ccivel, Al 1999301637,j. 19.03.2001, Desa. Izabel Vidal de Negreiros Leão)

145 A ementa completa desta belíssima decisão do STJ é: "Revisão de contrato - Arrendamento mercantil (leasing) - Relação de consumo - Indexação em moeda estrangeira (dólar) - Crise cambial de janeiro de 1999 Plano real. Aplicabilidade do art. 6 , inciso $\mathrm{V}$ do CDC - Onerosidade excessiva caracterizada. Boa-fé objetiva do consumidor e direito de informação. Necessidade de prova da captação de recurso financeiro proveniente do exterior. - O preceito insculpido no inciso $\mathrm{V}$ do artigo $6^{\circ}$ do $\mathrm{CDC}$ dispensa a prova do caráter imprevisivel do fato superveniente, bastando a demonstração objetiva da excessiva onerosidade advinda para o consumidor. - A desvalorização da moeda nacional frente à moeda estrangeira que serviu de parâmetro ao reajuste contratual, por ocasião da crise cambial de janeiro de 1999, apresentou grau expressivo de oscilaçāo, a ponto de caracterizar a onerosidade excessiva que impede o devedor de solver as obrigações pactuadas. - A equação econômicofinanceira deixa de ser respeitada quando o valor da parcela mensal sofre um reajuste que não é acompanhado pela correspondente valorização do bem da vida no mercado, havendo quebra da paridade contratual, à medida que apenas a instituição financeira está assegurada quanto aos riscos da variação cambial, pela prestação do consumidor indexada em dólar americano. - É ilegal a transferência de risco da atividade financeira, no mercado de capitais, próprio das instituições de crédito, ao consumidor, ainda mais que não observado o seu direito de informação (art. $6^{\circ}$, III, e 10, "caput", 31 e 52 do CDC). - Incumbe à arrendadora se desencumbir do ônus da prova de captação de recursos provenientes de empréstimo em moeda estrangeira, quando impugnada a validade da cláusula de correção pela variação cambial. Esta prova deve acompanhar a contestação (art. 297 e 396 do CPC), uma vez que os negócios jurídicos entre a instituição financeira e o banco estrangeiro são alheios ao consumidor, que não possui meios de averiguar as operaçōes mercantis daquela, sob pena de violar o art. $6^{\circ}$ da. Lei n. 8.880/94.(STJ, RESP 268661/RJ, 3ª Turma, Rel. Min. Nancy Andrighi, j. 16/08/2001) 
Boa-fé nos serviços bancários, financeiros , de crédito e securitários e o Código de Defesa do Consumidor

A riqueza desta linha de decisão está também em ter destacado que os riscos profissionais típicos inerentes à organização da cadeia de fornecimento deste tipo de negócio (por exemplo: decisão da fonte - no reduzido mercado nacional ou no exteriorde proveniência dos recursos usados para o financiamento do leasing) devem ser suportados pelos fornecedores e não podem ser transferidos para os consumidores (mesmo se lei ordinária assim autoriza), sendo abusiva a cláusula contratual que assim autorize. ${ }^{146}$ Estas decisões ainda destacam a importância do direito de informação dos consumidores e do dever de aconselhamento dos fornecedores -especialistas em leasing e em captação profissional de recursos para o negócio financeiro-frente aos consumidores leigos: " É ilegal a transferência de risco da atividade financeira, no mercado de capitais, próprio das instituiçōes de crédito, ao consumidor, ainda mais que não observado o seu direito de informação (art. 6\%, III, e 10, "caput", 31 e 52 do CDC). "(Resp. 268661 . RJ, Rel. Min. Nancy Andrighi, j. 16/08/2001).

Merece destaque o fato desta linha jurisprudencial ter bem evidenciado que a técnica do CDC, de assegurar direitos materiais ao consumidor, de modificação das cláusulas excessivamente onerosas, por exemplo, e de impor deveres de informação e de abstenção do abuso aos fornecedores, per se, influencia o direito processual de defesa do consumidor, ao impor ex vi lege determinadas provas ao fornecedor: " $A$ exigência de que a arrendadora prove a origem do dinheiro utilizado no contrato, para efeito de vinculação das contraprestaçôes à variação do dólar americano, não representa inversão quanto ao ônus da prova." (STJ, AGRESP 275391/MG, 3a Turma, Rel. Min. Carlos Alberto Menezes Direito, j. 19/06/2001).

${ }^{146}$ Neste sentido também a exemplar decisão do TJ-RJ, Rel. Sérgio Cavalieri Filho, j. 02.12.1999, em contrato denominado de Compra e venda de Faturamento, Assunção de dívida em Moeda estrangeira, cuja ementa ensina: "Bancos e financeiras, à luz do CDC, são fornecedores não apenas de serviços-cobrança de contas, tributos etc.- como também'me de produtos da atividade negocial das financeiras, crédito este que, quando concedido ao devedor para que o utilize como destinatário final, sujeita-se à disciplina do Código de Defesa do Consumidor por força do disposto em seus arts. $3^{\circ}, \S=2^{\circ}, 52$ e incisos. Viola o princípio da transparência a cláusula contratual que estabelece o reajuste das prestações pela variação do dólar sem que tenham sido dados ao consumidor todos os esclarecimentos necessários sobre os riscos e conseq6uencias da mesma, pelo que deve ser considerada ineficaz. Viola também dita cláusula o princípio da confiança na medida em que a súbita elevação do dólar frustou a legítima expectativa do consumidor de que teria condições de continuar pagando as prestações até o final do financiamento e, assim, adquirir definitivamente o seu veículo. A cláusula de reajuste pela variação do dólar viola, ainda, o princípio da boa-fé objetiva porque o financiador, através dela (Cláusula), procurou transferir para o consumidor os riscos do seu negocio, riscos esses que não the eram desconhecidos, tanto assim que deles procurou se livrar. $O$ CDC, em seu art. $6, V$, permite expressamente a revisão das cláusulas contratuais sempre que fatos supervenientes os tornem excessivamente onerosos. Ali não mais se exige que esses fatos supervenientes sejam imprevisiveis, como na clássica teoria da imprevisão, bastando que sejam inesperados. A questão da desvalorização do real frente ao dólar é, sem dúvida, típico caso de rompimento da base do negócio jurídico, pois, embora previsível, foi um fato não esperado pelo consumidor em face das constantes promessas do governo no sentido de não alterar a política cambial. Esse fato previsível, mas não esperado, situa-se na área do risco inerente a qualquer atividade negocial, não podendo ser transferido para o consumidor...", na íntegra in Direito do Consumidor, 34, p.281-287. 
Mencione-se, igualmente, que a doutrina alemã apoia-se também no direito comercial e em decisóes das cortes sobre o dever de atuar cooperativamente (Mitwirkungspflicht) oriundo do $§ 242$ do BGB (Cláusula geral de boa-fé) e do espírito societário ( $\$ 133$ e 140 HGB-Código Comercial Alemão). ${ }^{147}$ No direito brasileiro, face ao CDC parece também ser possível considerar-se a existência deste dever de renegociação a favor do consumidor, pois tanto o art. $6, \mathrm{~V}$ menciona o direito do consumidor de pedir a modificação do contrato em caso de onerosidade excessiva, quanto nos Art. 52 e 53 menciona o direito à informação, ao pagamento antecipado e devolução das quantias pagas. Logo, parece-me possível também no Brasil requerer a antecipação desta modificação e a cooperação do parceiro-fornecedor (dever de renegociação) para a readaptação do contrato (princípio de boa-fé do Art. 4,III) e sua manutenção (Art. 51,§ 2 ).

Note-se que a doutrina alemã também sugere um direito geral de denúncia dos contratos (cativos) de longa duração que levarem a parte mais fraca à ruína, ${ }^{148}$ hoje positivado no BGB. ${ }^{149}$ Semelhante direito poderia efetivamente ser extraído também no ordenamento jurídico brasileiro com base nos Art. 6,V e Art. 53 do CDC, de forma a evitar a morte do consumidor como homoeconomicus e resolver, mesmo que de forma indireta, os muitos problemas do superendividamento ${ }^{150}$ no país. $O$ direito de rescindir o contrato, mesmo inadimplente, é excepcional e só pode ser concedido à parte mais fraca, o consumidor, como se retira da ratio legis do Art. 54, $\S 2^{\circ}$, do Art. $51, \mathrm{XI}$ e $\S 2^{\circ}$, do Art. 52, §2, do Art. 53 e do Art. 6, V do CDC.

Em outras palavras, se o consumidor, no sistema do CDC, tem o direito (material) de devolução razoável das parcelas pagas (Art. 53), tem o direito de escolher continuar a relação ou rescindir (Art. $54, \S 2^{\circ}$ e Art. $51, \mathrm{XI}$ ), tem o direito de requerer ao juiz que modifique as cláusulas excessivamente onerosas por fatos supervenientes (Art. 6,V), e o sistema determina a continuação dos contratos (Art. $51, \$^{\circ}$ ), logo, parece-me que o consumidor tem o direito de propor a ação de rescisão e restituição das importâncias pagas (Art. 75 do CCB), mesmo que inadimplente. A jurisprudência do STJ tem sido sensível à esta necessidade subjetiva do consumidor, mesmo que já em estado de inadimplência, de conseguir rescindir os contratos cativos de longa duraçáo, de forma a evitar sua ruína ou o superendividamento definitivo, em especial em contratos de compromisso de compra e venda de imóveis. ${ }^{151}$

\footnotetext{
${ }^{147}$ Assim relata decisōes desde o Tribunal do Império (Reichsgericht), MARTINEK, p. 370 e seg.

148 Trata-se da sugestão de um novo $\S 361$, a para o BGB, sugestão também de Horn, relatada por MARTINEK, p. 396.

${ }^{149}$ Veja $\S 314$ e 641 do BGB-Reformado.

150 Veja Leitão Marques, p. 2.

${ }^{151}$ O leading case foi o Resp. 109.331/SP, Min. Ruy Rosado de Aguiar, DJ 31.03.97; "Justificado o inadimplemento pela superveniência de fato impeditivo do cumprimento do contrato, com desequilíbrio resultante da desvalorização da moeda, sucessiva aplicação dos planos econômicos e diferentes critérios para atualização dos créditos, pode o devedor pleitear a extinção do contrato". Veja também Resp. 109.960-/RS, Min. Ruy Rosado de Aguiar, DJ 24.03.97, Resp. 132.903/SP, Min. Ruy Rosado de Aguiar, DJ 19.12.97 e Resp. 79.489/DF, Min. Ruy Rosado de Aguiar, DJ 22.04.96.
} 
Boa-fé nos serviços bancários, financeiros, de crédito e securitários e o Código de Defesa do Consumidor

Repita-se que, segundo o STJ, tal direito é apenas do consumidor, face ao mandamento geral de manutenção dos contratos cativos de longa duração (Art. 52, $2^{\circ}$ ), e aos mandamentos especiais tutelares apenas dos consumidores de devolução razoável das parcelas pagas (art. 53), de cooperação e lealdade (Art. 6,VI) e de modificação das cláusulas tornadas excessivamente onerosas por fatos supervenientes (Art. 6,V). ${ }^{152}$

Importa frisar também que a teoria do adimplemento substancial (substancial performance) ${ }^{153}$ reforça a idéia que cabe apenas ao consumidor rescindir o contrato ou mantê-lo e que a melhor conduta do fornecedor é renegociar seus termos ou cooperar para que o consumidor possa adimpli-lo. ${ }^{154}$

Em outras palavras, quando as novas leis, como a de planos de saúde, exige uma inadimplência de 3 meses em um ano para que o fornecedor possa rescindir um contrato cativo de longa duração como este, a ratio legis é o dever de cooperação e o direito de manutenção dos contratos, ${ }^{155}$ o reverso da moeda, é a idéia que um 'pequeno'

\footnotetext{
${ }_{152}$ Assim depreende-se do Resp. 115.671/RS, Min. Waldemar Zveiter, DJ 02.10.00, interpretado, em voto-vista pelo min. Carlos Alberto Menezes Direito, in Resp. 200.019/SP, j. 17.05.2001, p. 4: "(Resp. 115.671/RS, DJ de 02.10.00), prevaleceu o voto do eminente Relator, o Senhor Ministro Waldemar Zveiter, no sentido de poder o comprador inadimplente 'pleitera em juízo a devolução das prestaçōes pagas e a rescisão do pacto, em face do desequilíbrio financeiro resultante da aplicaçāo dos sucessivos planos econômicos', presentes os artigos 51 e 53 do Código de Defesa do Consumidor...Alinhou-se o julgado, então, aos precedentes que permitem a iniciativa da ação ao comprador. Outros precedentes da $4^{\circ}$ turma seguem a mesma direção, admitindo que o 'comprador que deixa de cumprir o contrato alegando insuportabilidade da obrigação tem o direito de promover ação para receber a restituição das importâncias pagas', aplicando-se a regra do art. 924 do Código Civil..."

${ }_{153}$ Veja sobre a teoria Assis, Araken de. Resolução do contrato por Inadimplemento, S. Paulo, Ed. RT, 1991, p. 118 e seg. e Aguiar, Ruy Rosado de Jr. Do Incumprimento Contratual, Rio, Aide, 1991, p. 190 e seg.

${ }_{154}$ Assim jurisprudência do TA/RS, hoje TJ/RS: "Resolução extrajudicial. doutrina da substancial performance: sua invocabilidade. não é absoluto o direito formativo extintivo do promitente vendedor, ainda que expresso no instrumento contratual, na hipótese de mora. Se a prestaçāo do promitente comprador encontra-se substancialmente cumprida, ao outro figurante incumbe demonstrar o seu desinteresse pelo restante da prestação, por inútil. Hipótese em que $94 \%$ do preço do negócio de promessa de compra e venda de imóvel encontrava-se satisfeito. Apelo parcialmente provido" (ApC 194194866, 7.CC, Re. Antônio Janyr Dall'Agnol Júnior, j. 30.11.94), também da mesma Câmara, Apc 195134374, Rel.Vicente Barrôco de Vasconcello, j. 20.12.1995: "Hipótese em que faltante apenas metade de uma única prestação, havendo sido paga a quase totalidade das parcelas, isto é, oito e mais metade da última, portanto, o preço do negócio de promessa s de compra e venda de imóvel encontrase praticamente satisfeito e, em conseqüência, o contrato se encontra substancialmente cumprido." $E$ o leading case do TJ/RS: "Contrato. Resolução. Adimplemento substancial. O comprador que pagou todas as prestações de contrato de longa duração, menos a última, cumpriu substancialmente o contrato, não podendo ser demandado por resolução. Ação de rescisão julgada improcedente e procedente a consignatória." (ApC 588012666, j. 12.04.1988, Des. Ruy Rosado de Aguiar)

155 Assim decidiu recentemente o STJ, in Resp. 272739/MG, DJ 02.04.2001, Min. Ruy Rosado de Aguiar: "Alienação fiduciária. Busca e apreensão. Falta da última prestação. Adimplemento substancial. O cumprimento do contrato de financiamento, com a falta apenas da última prestação, não autoriza o credor a lançar mão da ação de busca e apreensāo, em lugar da cobrança da parcela faltante. O adimplemento substancial do contrato pelo devedor não autoriza ao credor a propositura de ação para a extinção do contrato, salvo se demonstrada a perda do interesse na continuidade da execução, que não é o caso. Na espécie, ainda houve a consignação judicial do valor da última parcela. Não atende à exigência de boa-fé objetiva a atitude do credor que desconhece esses fatos e promove a busca e apreensão, com pedido de reintegração de posse."
} 
inadimplemento do consumidor não é 'substancial ${ }^{156}$ o suficiente para causar a rescisão por decisão do credor adimplente, se este é um fornecedor, frente a consumidor. ${ }^{152}$ Como ensina o STJ em matéria securitária:

"SEGURO. INADIMPLEMENTO DA SEGURADA. FALTA DE PAGAMENTO DA ÚLTIMA PRESTAÇÃO. ADIMPLEMENTO SUBSTANCIAL. RESOLUÇÃO. A companhia seguradora não pode dar por extinto o contrato de seguro, por falta de pagamento da última prestação do prêmio, por três razóes: a) sempre recebeu as prestações com atraso, o que estava, aliás, previsto no contrato, sendo inadmissível que apenas rejeite a prestação quando ocorra o sinistro; b) a segurada cumpriu substancialmente com sua obrigação, não sendo a sua falta suficiente para extinguir o contrato; c) a resolução do contrato deve ser requerida em juízo, quando será possível avaliar a importância do inadimplemento, suficiente para a extinção do negócio.Recurso conhecido e provido" (Resp. 76362/MT, DJ 01.04.1996, Rel. Min. Ruy Rosado de Aguiar).

\section{Observações finais}

A todas estas tendências atuais, Canaris denominou de "tendências de materialização do direito das obrigaçōes contratuais" (Tendenz zu einer Materialisierung des Schuldvertragsrechts) ${ }^{158}$ Esta 'materialização' de Canaris teria duas vertentes: a materialização da liberdade contratual (Vetragsfreiheit), onde a determinação do conteúdo contratual não seria mais subjetiva, mas objetiva ou materializada pelas exigências da lei, dos princípios da confiança e da boa-fé é $^{159}$ e a materialização do equilíbrio ou justiça contratual (Vertragsgerechtigkeit), evoluindo-se para uma intervenção no conteúdo das obrigações a procura da função social dos contratos. ${ }^{160}$ Trata-se, pois, de uma nova teoria contratual, positivada no $\mathrm{CDC}$ e, agora, no novo Código Civil Brasileiro de 2002.

\footnotetext{
${ }^{156}$ Veja também no mesmo sentido El 197065436, TJ/RS, j. 14.03.1998, Des. Otávio Augusto de Freitas Barcelos: "Embargos Infringente. Seguro Total. Falta de pagamento da última prestação. Inadimplemento do segurado. Resolução contratual que deveria ter sido requerida em juízo. Adimplemento substancial. Devida a indenização pela perda total do bem. Precedentes do STJ." ${ }^{157}$ Assim ensina o TJ/RS, em caso de morte do segurado sem pagar a última prestação: "Comercial. Seguro. Falta de pagamento da última prestação pelo segurado. Irrelevância. Cobertura devida. E devida a cobertura do sinistro, mesmo que o segurado não pague a última parcela do prêmio, já que ocorreu adimplemento substancial (substantial performance) não admitindo o ordenamento pátrio a dissolução do vínculo fundada em inadimplemento relativo. Além do mais, a seguradora recebeu outras prestações após o vencimento. Precedentes do STJ" (ApC 595069923, j. 1.08.1996, Des. Araken de Assis)

${ }^{158}$ CANARIS, p. 276 e seg.

159 CANARIS,p. 277 e seg.

160 CANARIS,p. 289.
} 
Esta nova visão mais optimalizada da dogmática civilista encontra expressão no belo princípio da boa-fé objetiva e sua prática, como pretendemos demonstrar, ao compilar e organizar, nesta já longa demais exposição, a bela jurisprudência sobre boafé dos Tribunais brasileiros. Não se diga, pois que o julgador brasileiro não sabe agir frente às cláusulas gerais. Se com apenas uma cláusula geral, o Richterrecht (Direito dos juízes) braisileiro já é tão rico, imagine-se quando o sistema geral do direito privado, o $\mathrm{CC} / 2002$ entrar em vigor. Espera-se que neste momento, as relaçóes inter-comerciantes e entre civis, relações entre iguais, beneficiem-se desta experiência e desta prática das relações entre desiguais, um fornecedor e um consumidor.

julho de 2002 